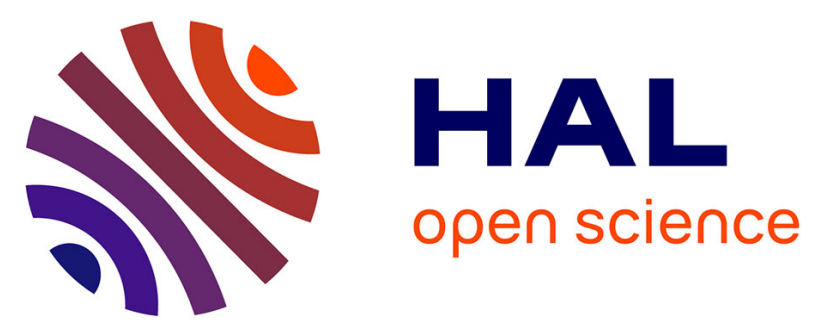

\title{
Diagenetic Evolution and Porosity Destruction of Turbiditic Hybrid Arenites and Siliciclastic Sandstones of Foreland Basins: Evidence from the Eocene Hecho Group, Pyrenees, Spain
}

H. Mansurbeg, M.A. Caja, R. Marfil, S. Morad, E. Remacha, Daniel Garcia, T. Martín-Crespo, M.A.K. El-Ghali, J.P. Nystuen

\section{To cite this version:}

H. Mansurbeg, M.A. Caja, R. Marfil, S. Morad, E. Remacha, et al.. Diagenetic Evolution and Porosity Destruction of Turbiditic Hybrid Arenites and Siliciclastic Sandstones of Foreland Basins: Evidence from the Eocene Hecho Group, Pyrenees, Spain. Journal of Sedimentary Research, 2009, 79 (9), pp.711-735. 10.2110/jsr.2009.060 . hal-00495021

\section{HAL Id: hal-00495021 \\ https://hal.science/hal-00495021}

Submitted on 2 Aug 2010

HAL is a multi-disciplinary open access archive for the deposit and dissemination of scientific research documents, whether they are published or not. The documents may come from teaching and research institutions in France or abroad, or from public or private research centers.
L'archive ouverte pluridisciplinaire HAL, est destinée au dépôt et à la diffusion de documents scientifiques de niveau recherche, publiés ou non, émanant des établissements d'enseignement et de recherche français ou étrangers, des laboratoires publics ou privés. 


\title{
Diagenetic evolution and porosity destruction of turbiditic hybrid arenites and siliciclastic sandstones of foreland basins: Evidence from the Eocene Hecho group, Pyrenees, Spain
}

\section{H. MANSURBEG (1,2), M.A. CAJA (3), R. MARFIL ${ }^{(3)}$, S. MORAD(1,4), E. REMACHA(5), DANIEL GARCIA $^{(6)} *$, T. MARTÍN-CRESPO(7), M.A.K. EL-GHALI ${ }^{(8)}$, J .P. NYSTUEN ${ }^{(9)}$}

(1) Department of Earth Sciences, Uppsala University, Villavägen 16, SE 75236 Uppsala, Suède

(2) AGR Petroleum, Karenslyst allé 4, P.O. Box 444, NO-0278 Oslo, Norway

(3) Departamento de Petrología y Geoquímica, Facultad de Geología, Universidad Complutense de Madrid, Avenida J ose Antonio Novais, s/n., 28040-Madrid, Espagne

(4) Department of Petroleum Geosciences, The Petroleum Institute, P.O. Box 2533, Abu Dhabi, United Arab Emirates

(5) Departament de Geologia, Universitat Autònoma de Barcelona, 08193 Bellaterra, Espagne

(6) Ecole Nationale Supérieure des Mines de Saint Etienne, Centre SPIN ; Département GENERIC ; UMR CNRS, 6524 LMV ; 158 Cours Fauriel ; 42023 Saint-Étienne Cedex 2, France

(7) ESCET, Universidad Rey J uan Carlos, Edificio Departamental I, 28933 Madrid, Espagne

(8) Department of Petroleum Geosciences, University Brunei Darussalam, Tungku Link, Gadong BE 1410, Brunei Darussalam

(9) Department of Geosciences, University of Oslo, P. O. Box 1047, Blindern, Oslo, Norvège

\begin{abstract}
This study aims to unravel the impact of diagenetic alterations on porosity loss of forelandbasin turbiditic hybrid arenites and associated siliciclastic sandstones of the Eocene Hecho Group (south-central Pyrenees, Spain).

In this succession, hybrid arenites and calclithites are extensively cemented by mesogenetic calcite cement $\left(\delta^{18} \mathrm{O}_{\mathrm{V}-\mathrm{PDB}}=-10.0 \%\right.$ o to $-5.8 \%$; $\mathrm{T}_{\mathrm{h}}$, mode $=80^{\circ} \mathrm{C}$; salinity mode $=18.8 \mathrm{wt} \%$ eq. $\mathrm{NaCl}), \mathrm{Fe}$-dolomite $\left(\delta^{18} \mathrm{O}_{\mathrm{V}-\mathrm{PDB}}=-8.5 \%\right.$ to $-6.3 \%$ o $)$ and trace amounts of siderite. The extent of carbonate cementation is interpreted to be related to the amounts of extrabasinal and intrabasinal carbonate grains, which provided nuclei and sources for the precipitation and growth of carbonate cements. Other diagenetic alterations, such as pyrite and albitization, had no impact on reservoir quality. Scarce early diagenetic cements, coupled with abundant ductile carbonate and siliciclastic framework grains, have led to rapid porosity loss owing to compaction. Conversely, abundant quartz in the sandstones prevented rapid loss of porosity by mechanical compaction.

Reservoir quality was affected by mesogenetic cementation by quartz overgrowths, calcite and dolomite intergranular pressure dissolution of quartz grains, and formation of fracture-filling calcite cement $\left(\delta^{18} \mathrm{O}_{\mathrm{V}-\mathrm{PDB}}\right.$ values from $-10.4 \%$ o to $-7.8 \%$; $\mathrm{T}_{\mathrm{h}}$ temperatures of $\approx 15 \mathrm{O}^{\circ} \mathrm{C}$ ), which
\end{abstract}

\footnotetext{
*Corresponding author : garcia@emse.fr
} 
are attributed to deep circulation of hot meteoric waters during extensional stages of tectonism. The results of this study illustrate that diagenetic evolution pathways of the arenites and sandstones are closely linked to the variation in detrital composition, particularly the proportion and types of extrabasinal noncarbonates, extrabasinal carbonates, and intrabasinal carbonate grains. These insights suggest that marine turbiditic hybrid arenites and calclithites of foreland basins are subjected to more rapid and extensive porosity loss owing to compaction and cementation than associated siliciclastic sandstones. Degradation of reservoir quality makes these hybrid arenites, calclithites, and sandstones suitable as tight gas reservoirs, but only if fracture porosity and permeability develop during tectonic deformation.

Keywords:

Arenites; Siliciclastic Sandstones; Foreland Basins; Eocene Hecho Group; Pyrenees; Spain; porosity loss; diagenetic evolution; carbonate cementation; Reservoir quality

\section{Introduction}

The diagenetic evolution of sandstones is complex and controlled by several interrelated parameters, including the tectonic setting of the basin and provenance (Morad et al. 2000), which exert a profound impact on the composition of the extrabasinal sand grains (Dickinson and Suczek 1979; Dickinson and Valloni 1980; Dickinson et al. 1983; Dickinson 1984; Lawton 1986; Schwab 1986). Although the impact of detrital composition on the mechanical and chemical stability and, hence, on burial diagenesis of sandstones is well documented (Bloch 1994), comparative diagenetic and related reservoir-quality evolution pathways of forelandbasin hybrid arenites and of closely associated siliciclastic sandstones are relatively poorly explored. Furthermore, only rarely is the diagenesis of such arenites integrated with the depositional facies and tectonostratigraphic evolution of the basins (e.g., Scholle 1971; Spadafora et al. 1998).

To address these gaps, this study explores the Hecho Group (southcentral Pyrenees) of the Aínsa-Jaca foreland Basin, Spain. Although the group has been subjected to intensive sedimentological, sequence stratigraphic, and tectonostratigraphic studies (Remacha et al. 1995; Soto and Casas 2001; Remacha et al. 2003; Jones et al. 2005; Remacha et al. 2005; Falivene et al. 2007; Bakke et al. 2008) because it is considered as world-class analogue for numerous deep-water turbidite reservoirs (Labourdette et al. 2008), less attention is given to diagenetic processes accounting for the pervasive porosity destruction of the turbiditic arenites (Fontana et al. 1989; Caja et al. 2007; Garcia et al. 2007). Elucidation of the impact of diagenesis on reservoir quality of marine turbidites is important because these deposits represent some of the foremost poorly explored. Furthermore, only rarely is the diagenesis of such arenites integrated with the depositional facies and tectonostratigraphic evolution of the basins (e.g., Scholle 1971; Spadafora et al. 1998).

To address these gaps, this study explores the Hecho Group (southcentral Pyrenees) of the Aínsa-Jaca foreland Basin, Spain. Although thegroup has been subjected to intensive sedimentological, sequence stratigraphic, and tectonostratigraphic studies (Remacha et al. 1995; Soto and Casas 2001; Remacha et al. 2003; Jones et al. 2005; Remacha et al. 2005; Falivene et al. 2007; Bakke et al. 2008) because it is considered as world-class analogue for numerous deep-water turbidite reservoirs (Labourdette et al. 2008), less attention is given to diagenetic processes accounting for the pervasive porosity destruction of the turbiditic arenites (Fontana et al. 1989; Caja et al. 2007; Garcia et al. 2007). Elucidation of the impact of diagenesis on reservoir quality of marine turbidites is important because these deposits represent some of the foremost important frontiers for hydrocarbon exploration (Spadafora et al. 1998; dos Anjos et al. 2000; Vilasi et al. 2006; De Ros and Goldberg 2007; Dutton 2008; Mansurbeg 2007; Mansurbeg et al. 2008). The results of this study illustrate the importance of tectonostratigraphy, depositional facies, and diagenetic evolution on the spatial and temporal distribution of reservoir quality, and hence aid hydrocarbon exploration in marine turbiditic arenite successions deposited in foreland basins. 


\section{Geological background}

The Pyrenees Mountains are an Alpine chain formed as a fold and thrust belt during the Late Cretaceous to early Miocene at the collision front between the Iberian and the Eurasian plates as a result of roughly north-south crustal contraction (Figure 1). At lithospheric scale, there are two main features (Muñoz 1992; Teixell 1998), including: (a) subducted Iberian lower crust beneath Eurasia, and (b) delaminated orogenic prism overlying the lower crust showing an asymmetric, fan-shaped body.

Within the orogenic prism, south-vergent structures dominate in number and extension, and form the south-Pyrenean zone, including the study area (Figure 1). Bedrock in this zone includes: (i) a Hercynian basement with granitoids and low-grade metamorphic rocks, (ii) a Mesozoic preorogenic sedimentary succession up to late Santonian, (iii) a synorogenic assemblage of Upper Cretaceous to lower Miocene sedimentary rocks, and (iv) a post-tectonic sedimentary succession, which is developed mostly in the Ebro basin (Figure 1).

The Eocene Hecho Group strata (Mutti et al. 1972) consist of a succession of turbidite systems filling a foredeep, here referred to as a turbidite wedge. The succession consists of five major unconformity-bounded tectonostratigraphic units, or TSUs (Remacha et al. 2003; Remacha et al. 2005), which reach a maximum thickness of about $4500 \mathrm{~m}$ (Figure 2). The boundaries between the TSUs record the main basin-modifying events and the greater stepwise depocentermigration onto the gently slopingmargin of the foreland basin (Figure 2). Consequently, the tectonic signature is expressed at the boundaries of the TSUs at southcentral Pyrenees scale, with these unconformities extending into adjacent basins. Thus, the stratigraphic succession of TSUs within the turbidite basin represents the more practical division that is linking major units. The TSUs can also be expressed in both the timeequivalent fluviodeltaic domain (Figure 3), developed to the east on a thrust-top basin (AgerTremp-Graus Basin), and the associated carbonate ramps of the southern margin of the foreland basin.

The five turbidite wedges (TSUs) fill the basin floor of a series of successive narrow and elongated foredeeps that are strongly controlled by the tectonic evolution of the basin. Each wedge consists of two main growth stages (cf. Mutti et al. 1985a; Mutti et al. 1985b): a lower sandy stage (type I and II), transitionally evolving upward into a muddy stage (type III) (Figure 3). The sandy deposits have a single entry point to the southeast (submarine canyon head) with the inner segment of the foredeep trending north-south. In the youngest turbidite systems of TSU-5, the general sediment entry point is dominant yet there was a northern supply known as the Rapitán system (Remacha et al. 1995), located North of Jaca.

\section{Methods}

A total of 241 very fine- to coarse-grained arenite samples were collected from fresh outcrops of four turbidite systems (TSU2-TSU5) of the Hecho Group (Figures 4, 5). Samples include various depositional facies within the Hecho Group (i.e., channel, channel-to-lobe transition, overbank, and sheetlike lobes; Figure 4A). Double-polished thin sections from each sample were stained for carbonates (alizarin red-s and potassium ferricyanide). Modal analyses from 84 representative samples (TSU-2: $\mathrm{n}=6$, TSU-3: $\mathrm{n}=29$, TSU-4: $\mathrm{n}=25$, and TSU-5: $\mathrm{n}=21$ ) with medium-sand median grain size $(0.25-0.5 \mathrm{~mm})$ and moderate to poor sorting were used to minimize compositional differences due to grain-size variations. Quantification of framework grains, porosity, and diagenetic minerals were obtained by counting 300 points per thin section. Modal abundances of framework grains are reported normalized to $100 \%$, whereas abundances of diagenetic components and porosity are relative to total rock volume (i.e., 300 counted points). Cathodoluminescence (CL) microscopy was carried out using a Technosyn 8200 MkII using $12-16 \mathrm{kV}$ accelerating voltage, 300-350 $\mu \mathrm{A}$ beam current, and 0.2-0.1 Torr vacuum pressure. The chemical composition of carbonate cements was determined by electron microprobe analysis (EMP) using a JEOL JXA-8900 with four detectors. Double-polished samples were coated with carbon film. Microprobe operation conditions were $15 \mathrm{kV}$ accelerating voltage, $20 \mathrm{nA}$ beam current, and $10 \mu \mathrm{m}$ beam size. 
Detection limits were approximately $250 \mathrm{ppm}$ for $\mathrm{Mn}, 200 \mathrm{ppm}$ for $\mathrm{Fe}, 100 \mathrm{ppm}$ for $\mathrm{Mg}$, 400 $\mathrm{ppm}$ for $\mathrm{Ca}$, and $27 \mathrm{O} \mathrm{pm}$ for Sr. For comparison purposes, the results were normalized to 100 mole \% of $\mathrm{CaCO}_{3}, \mathrm{MgCO}_{3}, \mathrm{FeCO}_{3}$, and $\mathrm{MnCO}_{3}$.

Bulk-rock stable carbon and oxygen $\left(\delta{ }^{13} \mathrm{C}\right.$ and $\left.\delta{ }^{18} \mathrm{O}\right)$ isotope analyses were conducted on carbonate cement and detrital carbonate grains in 21 samples. Two steps of reaction with phosphoric acid were used to separate calcite $\left(\mathrm{CO}_{2}\right.$ extracted after three hours at $\left.25^{\circ} \mathrm{C}\right)$ from dolomite $\left(\mathrm{CO}_{2}\right.$ extracted after 24 hours at $50^{\circ} \mathrm{C}$ ) in whole-rock powders (Al-Aasm et al. 1990). Isotopic ratios are reported in per mil relative to the V-PDB standard. Values were calibrated using NBS-19 as the primary standard, and analytical precision was better than $0.05 \%$.

Thirty polished sections were studied for chemical composition of feldspars and were then examined in BSE images, using a JEOL JXA-8900 electron microprobe with four detectors (15 kV accelerating voltage, $21.5 \mathrm{nA}$ beam current, and $5 \mu \mathrm{m}$ beam size). Fluid-inclusion microthermometry was carried out on a Linkam THMSG 600 heating-cooling stage attached to an Olympus BH-2 microscope equipped with a longfocal-distance lens (80 X). The apparatus was calibrated at low temperature by inclusion of pure $\mathrm{CO}_{2}$ in topaz $\left(-56.6^{\circ} \mathrm{C}\right)$ and synthetic inclusions of pure water in quartz $\left(0.015^{\circ} \mathrm{C}\right)$ and at high temperature by known standard melting temperature provided by Merck. Vitrinite reflectance analyses included the measure of up to 100 points per sample in the organic matter. Vitrinite fragments displaying evidence of recycled origin were not observed in the studied samples.

\section{Results detrital composition}

\section{IV.1. Hybrid Arenites and Calclithites}

Noncarbonate extrabasinal (NCE), carbonate extrabasinal (CE), and carbonate intrabasinal (CI) components (sensu Zuffa 1980) of the Hecho Group arenites (Figure 6A) reveal that TSU-3 (Torla, Broto, Gerbe, and Cotefablo turbitide systems), TSU-4 (Banastón turbitide system) and TSU-5 (Aínsa, Morillo, and Guaso turbitide systems) are made up of hybrid arenites (sensu Zuffa 1980) and calclithites (sensu Pettijohn et al. 1972). Calclithites are rich in CE grains, such as dolostones, dolomicrite, discrete rounded dolomite crystals with grain size similar to other grain types, grainstones, sparitic and micritic limestones, micritic fossiliferous limestones, and discrete sparitic crystals (Table 1). Hybrid arenites are characterized by the occurrence of CI grains, which include mainly Eocene foraminifera and skeletal fragments of shallow-water organisms (foramol facies), intraclasts, peloids, and phosphate fragments (Table 1).

Below, "hybrid arenites" refers to both hybrid arenites (sensu stricto) and calclithites to simplify the comparison of diagenetic processes affecting carbonate-rich arenites and siliciclastic sandstones.

Total feldspar content in the hybrid arenites is variable, from $1 \%$ to $18 \%$ (of total rock volume) but can reach up to $41 \%$ (Figure 6B). K-feldspar and plagioclase are partly replaced by clay minerals and carbonates. Kfeldspar content ranges from $1 \%$ up to $8 \%$, (TSU-3, Torla), and plagioclase ranges from $1 \%$ to $16 \%$ (TSU-4, Banastón 1 and 2; Table 1). Monocrystalline quartz (16\% to $28 \%$ ) is more abundant than polycrystalline quartz grains (5\% to $9 \%$ ). Chert grains range in abundance from $1 \%$ to $3 \%$, lithic rock fragments from $1 \%$ to $3 \%$, and mica (dominantly muscovite) and heavy minerals are present in amounts less than $1 \%$.

Abundance of the lithic rock fragments and extrabasinal CE (Figure 6C) increases upwards, from $41 \%$ in $\mathrm{TSU}-3$ to $46 \%$ in $\mathrm{TSU}-4$ to $55 \%$ in TSU-5 (Table 1). Lithic grains include metamorphic (MRF), plutonic (PRF), and sedimentary (SRF) rock fragments. The TSU-3 arenites contain dominantly SRF (up to $1 \%$ ), whereas the TSU- 4 and TSU- 5 contain greater amounts of SRF ( $2 \%$ and $3 \%$, respectively) and MRF ( $3 \%$ and $1 \%$, respectively) than PRF (1\% in TSU-4 and TSU-5). The MRF are of high-, medium-, and low-grade origins (phyllites and metasandstones). Sedimentary rock fragments, which dominate in TSU-3, are mainly sandstones, mudrocks, and chert. Other lithic grains include minor amounts of volcanic rock fragments, subvolcanic alkaline (basalt), and acidic (andesite-rhyolite), which are most abundant in TSU-5 (Table 1). Total feldspar content increases upwards, from 10\% in TSU-3, 
to $16 \%$ in TSU-4, to $16 \%$ in TSU-5, (Table 1 ). Abundance of monocrystalline and polycrystalline quartz grains decreases from TSU-3 to TSU-5 (79\% in TSU-3, 64\% in TSU-4, and $63 \%$ in TSU-5).

\section{IV.2. Sandstones}

The sandstones occur only in the lowermost unit of TSU-2. Plotted on a QFL ternary diagram (Q, quartz; F, feldspars; L, lithic fragments, including chert of volcanic and sedimentary origin; Pettijohn et al. 1972), the sandstones are classified as quartzarenites (Figure 6B). Monocrystalline quartz is more abundant (up to 67\%) than polycrystalline grains (up to $18 \%$ ). Detrital feldspars $(<6 \%)$ include equal proportions of plagioclase and K-feldspars. Lithic grains in the siliciclastic sandstones are scarce $(<2 \%)$ and include metamorphic and sandstone rock fragments. Conversely, CE grains are abundant (up to $40 \%$, average of $18 \%$; Figure 6C), which include dominantly dolostone (up to 13\%), micritic limestones (up to 10\%), and bioclasts (up to $8 \%$; Table 1). Muscovite occurs up to $3 \%$, and heavy minerals, mainly tourmaline and zircon, are present in minor amounts, up to $2 \%$.

\section{Petrology and chemistry of diagenetic minerals}

\section{V.1. Calcite Cement}

Intragranular, intergranular, and scarce fibrous circumgranular calcite cement occurs in the siliciclastic sandstones and the hybrid arenites but is most abundant in the hybrid arenites of TSU-5, in which they compose up to $31 \%$ of the rock (Table 1). Intragranular ferroan calcite cement displays reddish-brown luminescence and equant mosaic texture, and engulfs pyrite in the skeletal grains, particularly the foraminifera (Figures $7 \mathrm{~A}-\mathrm{F}$ ). The chemical composition of this calcite is similar in all turbidite systems (Figure 8, Table 2). Blocky to poikilotopic, ferroan calcite crystals occur as grain-displacive, intergranular cement $(150-1200 \mu m$; Table 1, Figures 9A, B). This cement displays various luminescence colors, including: (i) red circumgranular crystals engulfed by nonluminescent calcite (Figures 9C, D), and (ii) nonluminescent to dark-red calcite crystals (Figures 9E, F). Small amounts of calcite cement occur also as syntaxial overgrowths around echinoderms being engulfed by, and hence predating, intergranular poikilotopic calcite cement.

Electron microprobe analyses revealed that the intergranular and intragranular carbonate cements are ferroan calcite (Table 2; Figure 8). Fe content ranges from 630 to $15981 \mathrm{ppm}$ in all TSU, Mn is up to $1231 \mathrm{ppm}, \mathrm{Ba}$ is up to $2553 \mathrm{ppm}$, and $\mathrm{Sr}$ varies nonsystematically within the different TSU from below the detection limit up to $12143 \mathrm{ppm}$ (Table 3).

Intergranular calcite cement in arenites from TSU-4 (Banastón 5) contains primary fluid inclusions based on their occurrence along crystal growth lines. Homogenization temperatures $\left(\mathrm{T}_{\mathrm{h}}\right)$ range from $70^{\circ} \mathrm{C}$ to $120^{\circ} \mathrm{C}$, with modal values of $80^{\circ} \mathrm{C}$. Final melting of ice ranges between -14.2 and $-17^{\circ} \mathrm{C}$ (mode $-15.2^{\circ} \mathrm{C}$ ), indicating salinities of $17.9-20.2$ wt \% eq. $\mathrm{NaCl}$ (mode $=18.8$ wt \% eq. $\mathrm{NaCl}$ ). Eutectic temperatures lower than $-40^{\circ} \mathrm{C}$ are characteristic of the $\mathrm{H}_{2} \mathrm{O}-\mathrm{NaCl}-\left(\mathrm{CaCl}_{2}\right)$ system. Scarce, small $(<5-40 \mu \mathrm{m})$, primary fluid inclusions in veinfilling calcite cement show higher $\mathrm{T}$ values $\left(145\right.$ to $162^{\circ} \mathrm{C}$; mode $\left.=150^{\circ} \mathrm{C}\right)$ than those measured in the intergranular cement. Final melting of ice displays values from -0.8 to $-2^{\circ} \mathrm{C}$, indicating relatively low salinities ( 1.3 to 3.3 wt \% eq. $\mathrm{NaCl}$; mode of 2.3 wt \% eq. $\mathrm{NaCl}$ ). Intergranular calcite cement has $\delta^{18} \mathrm{O}_{\text {V-PDB }}$ values that range from $-10.0 \%$ to $-5.8 \%$ and $\delta{ }^{13} \mathrm{C}_{\mathrm{V}-\mathrm{PDB}}$ from $2.7 \%$ o to +0.4\%o (Table 4).

The red luminescent, fibrous circumgranular calcite cement (40-60 $\mu \mathrm{m}$ wide) is most abundant in the sandstones of the TSU-2, i.e., in the lowermost and most deformed tectonostratigraphic unit (Figures 10A, B). This cement shows the highest $\mathrm{Sr}$ content among the carbonate cements (1640 to $5978 \mathrm{ppm}$ ), whereas $\mathrm{Fe}, \mathrm{Mn}$, and Ba contents are relatively low (2340 to $6179 \mathrm{ppm}$; up to $720 \mathrm{ppm}$; and up to $484 \mathrm{ppm}$, respectively) (Tables 2 and 3, Figures 8). Fibrous calcite cement has $\delta^{18} \mathrm{O}_{\mathrm{V}-\mathrm{PDB}}$ values close to $-9.7 \%$ and $\delta^{13} \mathrm{C}_{\mathrm{V}-\mathrm{PDB}}$ values varying from $+0.7 \%$ o to $+0.4 \%$ (Table 4 ; Figure 11 ). 


\section{V.2. Vein Calcite}

Vein calcite, which is common in siliciclastic sandstones of TSU-2 and occasionally in the lowermost part of the hybrid arenite units (TSU-3), occurs as prismatic to coarse blocky crystals ( $>2 \mathrm{~mm}$ : Figure $10 \mathrm{C}, \mathrm{D}$ ) with curved faces and concavo-convex and sutured intercrystalline contacts. Barite crystals are scattered between the blocky calcite crystals. Some of the calcite crystals are saddle shaped with sweeping extinction, and curved crystal faces occur in the veins. Vein, blocky, and prismatic calcites have $\delta^{18} \mathrm{O}_{\mathrm{v}-\mathrm{PDB}}$ values from $-10.4 \%$ o to $-7.8 \%$ ond $\delta^{13} \mathrm{C}_{\mathrm{V}-\mathrm{PDB}}$ from $-1.8 \%$ o to $-1.4 \%$ o (Table 4 , Figure 11 ).

\section{V.3. Dolomite Cement and Overgrowths}

Dolomite cement occurs in small amounts in the siliciclastic sandstones and in the hybrid arenites but may reach amounts as high as $23 \%$ in sandstones from TSU-2 and up to $12 \%$ in the hybrid arenites of TSU-5 (Guaso unit; Table 1). Dolomite cement occurs as small $(<20 \mu \mathrm{m})$, scattered crystals, or as aggregates of few crystals in the intergranular pores or as rims around the framework grains (Figures 9A, B, 11A, B). These scattered dolomite rhombs, which occur in small amounts $(<2 \%)$ in all TSUs, are engulfed by, and hence predate, intergranular ferroan calcite cement (Figures 12A, B). No textural differences were observed between the dolomite cement in the siliciclastic sandstones and the hybrid arenites.

Dolomite cement occurs also as syntaxial overgrowths $(50-100 \mu \mathrm{m}$ wide) around detrital monocrystalline dolomite grains present in the siliciclastic sandstones and the hybrid arenites (Table 1). The dolomite core is nonluminescent, whereas the overgrowths show bright orange luminescence (Figures 12C, D). Two zones of dolomite overgrowths were distinguished using backscattered electron imaging (Figures 12E, F). The early dolomite overgrowth is characterized by relatively low $\mathrm{Mn}$ and Fe contents (up to $1928 \mathrm{ppm}$ and $84009 \mathrm{ppm}$, respectively), whereas the later overgrowths are richer in $\mathrm{Mn}$ and Fe (up to $1928 \mathrm{ppm}$ and $84009 \mathrm{ppm}$, respectively; Table 2). The small amounts and small size of the overgrowths precluded obtaining separate isotopic analyses for the diagenetic and detrital dolomite. Bulk detrital dolomite and the overgrowths have $\delta^{18} \mathrm{O}_{\mathrm{V}-\mathrm{PDB}}$ values that range from $-8.5 \%$ o to $-6.1 \%$ o and $\delta_{13} \mathrm{C}_{\mathrm{V} \text {-PDB }}$ from $-1.2 \%$ o to $+0.7 \%$ o (Figure 11, Table 4 ) and are, thus, largely similar to stableisotope values for some of the intergranular calcite cements. Some of the samples contain trace amounts of siderite cement $(<1 \%$; occasionally up to $10 \%$ in calclithites of the Banastón 5 unit) composed of small $(<20 \mu \mathrm{m})$ scattered crystals or groups of few crystals replacing carbonate bioclasts and lithic grains.

V.4. Albite

Feldspar grains in the sandstones and the hybrid arenites display petrographic features similar to albitized feldspars described by Morad (1986), Morad et al. (1990), and Saigal et al. (1988), such as the irregular and obliterated twinning planes, and the presence of untwinned, vacuolated feldspar grains that display patchy extinction patterns.

Nonluminescent diagenetic albite occurs as overgrowths on primary green-to-blue luminescent plagioclase. Diagenetic albite overgrowths on plagioclase and albitized K-feldspar grains are engulfed by, and hence predate, ferroan calcite cement (Figures 13A, B). Most of the diagenetic albite has replaced K-feldspar and plagioclase (Figures 13C, D). In many cases, calcite cement has selectively replaced the non-albitized parts of the detrital feldspar while the albitized part remained unaffected (Figures 13E, F). Electron microprobe analysis of albite overgrowths shows nearly pure end-member composition (99.9 mol \% Ab), whereas albite replacing plagioclase grains has more variable composition (nil to $2.6 \mathrm{~mol} \% \mathrm{An}$; Table 5, Figure 14). Scarce, coarse barite crystals are closely associated with albitized K-feldspars.

\section{V.5. Quartz and Pyrite}

Quartz cement occurs as syntaxial overgrowths around the monocrystalline quartz grains (up to $4 \%$ in TSU-5, Morillo unit; Table 1). Pyrite occurs in trace amounts $(<1 \%)$ as framboids within carbonate bioclasts in most of the studied samples. Pyrite is engulfed by, and thus predates, intergranular, coarsely crystalline, ferroan calcite cement (Figures 15A, B). Organic matter associated with pyrite is composed of vitrinite, inertinite, and bituminite. The mean 
vitrinite reflectance (Ro) measured in TSU-3 is $0.9(\mathrm{n}=25)$, TSU-4 is $0.39(\mathrm{n}=34)$ and TSU5 is $1.51(\mathrm{n}=5)$ (Barker and Pawlewicz 1994) indicates temperatures of $128^{\circ} \mathrm{C}, 62^{\circ} \mathrm{C}$, and $169^{\circ} \mathrm{C}$, respectively.

\section{V.6. Compaction Features and Porosity}

Primary intragranular porosity in bioclasts was completely occluded by ferroan calcite cement. Primary intergranular porosity has been nearly completely destroyed in the siliciclastic sandstones and the hybrid arenites. In both rock types, physical and chemical compaction are the dominant processes causing porosity loss. Mechanical compaction is indicated by bending of mica grains and plastic deformation of ductile sedimentary and metasedimentary (slates and phyllites) as well as carbonate grains (Figures 15C, D). In the siliciclastic sandstones, chemical compaction is evidenced by intergranular straight, concavoconvexand sutured contacts that occur along the quartz-quartz and carbonatecarbonate grain contacts (Figure $15 \mathrm{E}$ ).

Total intergranular volumes (i.e., the sum of intergranular pore space and intergranular cement) of hybrid arenites are relatively low (10-20\%; Table 1). Siliciclastic sandstones in TSU-2, however, have total intergranular volumes up to $47 \%$. Minor secondary porosity (1$2 \%$ ) occurs in the hybrid arenites and in the sandstones, formed by dissolution of coarsely crystalline, intergranular calcite cement and carbonate grains. Open fracture porosity was not observed. Fractures in the siliciclastic sandstones from TSU-2 and TSU-3 are completely filled by carbonate cement.

\section{Discussion}

\section{VI.1. Paragenetic Sequence}

The petrographic data suggest that diagenetic alterations of the Hecho Group, which are interpreted to have been accomplished during eodiagenesis $(<2 \mathrm{~km}$ depth $)$ and mesodiagenesis (>2 km) (sensu Morad et al. 2000), vary significantly among the turbiditic hybrid arenites and the sandstones. Due to the lack of a detailed knowledge of the burial history of the succession, it is difficult to interpret the exact timing and burial depths or temperatures for all of the diagenetic processes and products. Nevertheless, an overall paragenetic sequence was established based on superposition and textural relationships of various diagenetic alterations and on the fluid-inclusion analyses (Figure 16). Eogenetic alterations in the hybrid arenites include: (i) precipitation of minor amounts of framboidal pyrite from marine pore waters within carbonate bioclasts, reflecting local reducing conditions (Raiswell 1997; Schieber 2002), (ii) precipitation of ferroan calcite cement in intragranular pores of bioclasts, (iii) cementation by intergranular poikilotopic ferroan calcite, and (iv) intense mechanical compaction favored by the presence of abundant ductile framework grains (primarily sedimentary, shale and siltstones, vitreous volcanic rock fragments, lowgrade metamorphic rock fragments, and carbonate intraclasts). Mesogenetic alterations include: (i) pressure dissolution (i.e., chemical compaction) of the carbonate grains, (ii) cementation by intergranular blocky ferroan calcite, (iii) precipitation of dolomite overgrowths, and (iv) albitization of detrital feldspars and development of albite overgrowths. Eogenetic alterations in the siliciclastic sandstones include: (i) fibrous circumgranular calcite cement, (ii) minor amounts of framboidal pyrite from marine pore waters precipitating within the carbonate bioclasts, and (iii) cementation by intergranular poikilotopic ferroan calcite and dolomite cement. Mesogenetic alterations in the sandstones include: (i) intergranular pressure dissolution (i.e., chemical compaction) of detrital quartz grains and concomitant formation of quartz overgrowths, (ii) cementation by intergranular blocky ferroan calcite, (iii) precipitation of dolomite overgrowths, (iv) albitization of detrital feldspars with development of albite overgrowths, and (v) formation of vein-filling calcite and scarce barite crystals in TSU-2. Dissolution of coarsely crystalline, intergranular calcite cement and carbonate grains giving secondary porosity occurs in the hybrid arenites and the sandstones. There are no pronounced differences in diagenetic evolution of the siliciclastic sandstones and hybrid arenites among the studied TSUs and various depositional facies (e.g., channel, channel-to- 
lobe transition, overbank, and sheetlike lobes; Figure 4A). Thus, variations in the diagenetic evolution pathways can be attributed mainly to variation in the detrital compositions, particularly the proportion and types of extrabasinal noncarbonate grains (feldspar and lowgrade metamorphic rock fragments), extrabasinal carbonate grains, and intrabasinal carbonate grains (Figures 6,17), which do not show any systematic facies control.

\section{VI.2. Distribution and Conditions of Carbonate Cementation}

Cementation of the turbiditic hybrid arenites by carbonate was enhanced by the presence of abundant carbonate grains, which can act as nuclei for the precipitation and growth of carbonate cement (cf. South and Talbot 2000; Ketzer et al. 2002; Ketzer et al. 2003; El-Ghali et al. 2006).

Pressure dissolution of the carbonate grains rendered them assources of carbonate cement (Morad 1998). However, the common occurrence of fibrous circumgranular calcite (Figure $7 \mathrm{~A}, \mathrm{~B}$ ), which is commonly considered as typical marine cement (Tucker and Wright 1990), in arenites of TSU-2 and TSU-3 suggests that eogenetic calcite cement was also sourced by marine pore waters. Cementation by fibrous circumgranular calcite may have been promoted by diffusion of dissolved $\mathrm{Ca}^{2+}$ and $\mathrm{HCO}_{3}{ }^{-}$from the overlying seawater (Kantorowicz et al. 1987; Ketzer et al. 2003). Thus, cementation by fibrous calcite likely commenced near the seafloor (Kendall 1985; Tobin et al. 1996). Fibrous calcite in marine sediments has been interpreted to be derived from the neomorphism of aragonite and/or high-Mg calcite (Tucker 1986; Moore 1989). The high Sr content (up to 6000 ppm; Figure 8) of this calcite may support an aragonitic precursor (Tucker 1986; Moore 1989; Tucker and Wright 1990), whereas the relatively high amounts of $\mathrm{Fe}$ in these calcites suggest precipitation from suboxic to anoxic pore waters (Froelich et al. 1979). The reason behind limited amounts of fibrous calcite in TSU-4 and TSU-5 is unclear but could be caused by relatively short residence time of the sediments near the seafloor due to high sedimentation rates during deposition of these units (cf. Morad et al. 2000; Ketzer et al. 2003).

The $\delta_{13} \mathrm{C}_{\mathrm{V} \text {-PDB }}$ values of fibrous calcite ( $+0.4 \%$ o to $+0.7 \%$ ) also suggest derivation of dissolved carbon from seawater or from the dissolution of detrital marine carbonate grains. However, the low oxygen isotope values of the calcite cements $\left(\delta^{\mathrm{is}} \mathrm{O}_{\mathrm{v}-\mathrm{PDB}} \approx-9.7 \%\right.$ o $)$ are indicative of formation at elevated temperatures or from meteoric water (Morad 1998). Assuming that these calcite cements, which commonly fill small pores in compacted sandstones, are derived from evolved basinal brines with $\delta^{18} \mathrm{O}_{\mathrm{v} \text {-smow }}$ value of $+2 \%$, the $\delta^{18} \mathrm{O}_{\mathrm{v}-\text {-pD }}$ values of calcite would indicate precipitation temperatures of $55^{-}-90^{\circ} \mathrm{C}$, whereas precipitation from meteoric waters

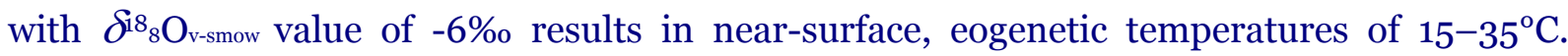
Nevertheless, the rapid loss of porosity and permeability of the arenites, which are rich in ductile grains (Nagtegaal 1978; Pittman and Larese 1991), particularly by mechanical compaction, probably precluded influx of considerable volumes of meteoric waters into the arenites. Hence, the fibrous calcite might have been recrystallized at elevated temperatures (Saigal and Bjorlykke 1987) and stretched by tectonic shear stresses.

Cementation of the arenites by intragranular ferroan calcite (Figure 8) probably occurred in the $\mathrm{Mn}-\mathrm{Fe}$ reduction geochemical zone below the seafloor (Froelich et al. 1979). The intergranular patches of blocky to poikilotopic calcite cement are suggested to have been sourced by dissolution of carbonate grains and pressure dissolution of these components during progressive burial. The low and variable $\delta^{18} \mathrm{O}$ v-pDв values of the intergranular calcite cement $\left(-10.0 \%\right.$ to $-6.0 \%$ o) suggest precipitation at temperatures of $35-50^{\circ} \mathrm{C}$ if a preQuaternary marine water $\delta^{i 8} \mathrm{O}_{\mathrm{v}-\text { smow }}$ value of $-1.2 \%$ (Shackleton and Kenneth 1975) is assumed. Higher temperatures (ca. $50-75^{\circ} \mathrm{C}$ ) are obtained if precipitation is assumed to have occurred

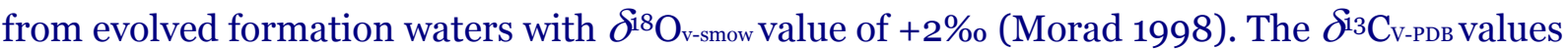
$(-1.4 \%$ o to $+0.4 \%$ o $)$ are consistent with derivation of dissolved carbon from the dissolution of detrital marine carbonate grains. 
Calculated precipitation temperatures for intergranular blocky calcite cement from fluidinclusion analyses $\left(\approx 80^{\circ} \mathrm{C}\right.$; Figure 17$)$ and the high salinity (ranging from 17.9 to $20.2 \mathrm{wt} \%$ eq. $\mathrm{NaCl}$ ) support an interpretation of precipitation from hot basinal fluids, probably sourced from the underlying Upper Triassic evaporitic deposits (Díaz Merino et al. 2006). Low oxygen isotope values $\left(\delta^{\mathrm{i} 8} \mathrm{OV} \mathrm{VDB}=-10.4 \%\right.$ o $-7.9 \%$ ), high measured $\mathrm{Th}\left(\approx 15 \mathrm{O}^{\circ} \mathrm{C}\right)$, and low salinities of vein calcite that crosscuts all other diagenetic carbonates suggest formation from hot meteoric waters (Bitzer et al. 2001; Ferket et al. 2004). Meteoric-water infiltration into these tight arenites is expected to have influenced only host rock in the vicinity of fractures, which were formed during uplift and deformation of the foreland basin (Spadafora et al. 1998). The orientation of the calcite crystal growth perpendicular to the vein walls (Figure $7 \mathrm{C}$ ) indicates that meteoric-water flux and cementation occurred during extensional deformation of the sandstones (Travé et al. 1997; Bodego and Agirrezabala 2007). The occurrence of saddle-like calcite crystals may indicate a dolomite precursor, which is typical high-temperature carbonate cement formed at temperatures greater than $70^{\circ} \mathrm{C}$ (Spötl and Pitman 1998). The replacement of fracture-filling saddle dolomite is attributed to flux of hot meteoric waters (Zeeh et al. 2000; Marfil et al. 2005).

Petrographic evidence suggests the presence of two generations of dolomite cement, including early scattered dolomite crystals that precipitated around the framework grains (particularly around extrabasinal dolostone grains), followed by chemically zoned, syntaxial dolomite overgrowths. The grain-coating dolomite cement is interpreted to have been precipitated at or near to the seafloor from marine pore waters, and could have been sourced by the dissolution of high-Mg bioclasts and by the alteration of volcanic rock fragments (Morad 1998).

Formation of microcrystalline calcite and dolomite cements around the carbonate grains at shallow depths below the seafloor may be sourced bydiffusion of $\mathrm{Mg}^{2+}, \mathrm{Ca}^{2+}$, and $\mathrm{HCO}_{3}{ }^{-}$from the overlying seawater (Wilkinson 1989). The chemical zonation in dolomite overgrowths (Figure 8) presumably mimics variations in the concentrations of dissolved Fe and $\mathrm{Mn}$ in the pore waters, which might reflect changes in pore-water chemistry owing to mixing zones, Eh fluctuations in the reactant fluid, or variations in the supply of Fe and Mn ions, possibly from terrestrial input (Hendry et al. 2000).

The $\delta^{13} \mathrm{C}_{\mathrm{V}-\mathrm{PDB}}$ values of bulk dolomite $(-1.2 \%$ to $+0.7 \%$ o $)$ suggest derivation of dissolved carbon from marine pore waters and/or from dissolution of marine carbonate grains. Assuming precipitation from marine pore waters, the narrow range of low oxygen isotope values in dolomite cement ( $\delta_{18} \mathrm{O}$ from $-8 \%$ o to $-6 \%$ o) would indicate precipitation at elevated temperatures. Using the fractionation equation of Land (1983), precipitation temperatures of $60-75^{\circ} \mathrm{C}$ are obtained with a pre-Quaternary marine water $\delta^{18} \mathrm{O}_{\mathrm{v} \text {-smow }}$ value of $-1.2 \%$


precipitation occurred from evolved marine pore waters with $\delta^{\mathrm{i} 8} \mathrm{O}_{\mathrm{v}-\text { smow }}$ value of $+2 \%$. The lack of correlation between $\delta^{18} \mathrm{O}$ and $\delta^{13} \mathrm{C}$ values (Figure 11) may be the result of derivation of dissolved carbon from dissolution of detrital carbonate grains in the host sediments, independently of the variation in temperature, and hence in $\delta^{\mathrm{i} 8 \mathrm{O}}$ values.

Variation in the amount of cementation was controlled not only by the amounts of detrital carbonate grains but also by the residence time of the sediments near the seafloor (i.e., sedimentation rates; Wilkinson 1989; Morad et al. 2000).

Dolomite cement similar to that in the arenites is present in the condensed sections within the lowstand wedges of depositional sequences in the Eocene Hecho Group (Marfil et al. in press). Textural relationships and chemical composition suggest an early diagenetic origin for microcrystalline dolomite, which could be similar to the grain-coating dolomite reported in this paper. In the condensed episodes (dolomite in yellow beds, Figure 11), the dolomite overgrowths show $\delta^{i 8} \mathrm{O}$ values comparable to detrital dolomites and overgrowths of the turbidite arenites (from -8.5 to $-6.3 \%$ o $\delta^{8} 8 \mathrm{O}$, Table 4 ), which could indicate that cementation 
by dolomite continued during deeper burial (Hendry et al. 2000; Aqrawi et al. 2006; Machent et al. 2007).

\section{VI.3. Origin and Conditions of Albitization}

Albite can be of detrital or diagenetic origin. The petrographic evidence from this succession suggests that albite in the sandstones and the hybrid arenites was formed by the replacement (i.e., albitization) of detrital plagioclase and K-feldspars. Diagenetic albitization in sandstones is controlled by temperature, chemistry of formation water, and reaction kinetics (Boles 1982; Aagaard et al. 1990; Morad et al. 1990). Albitization is also a common feature of hydrothermally altered granitic source rocks (Varlamoff 1972). Evidence of diagenetic albitization in these sandstones include: (i) absence of sericite and epidote, which typically occur in hydrothermally albitized feldspars (Zurcher et al. 2005), (ii) occurrence of both of grain-replacive albite and euhedral albite overgrowths (Figures 13A,B), indicating that the overall geochemical conditions were suitable for albite formation in the arenites, (iii) nearly pure chemical composition of the replacive albite and of albite overgrowths (Morad 1986; Saigal et al. 1988), and (iv) lack of luminescence of the albite overgrowths and albitized grains (Figure 13C-F; Kastner and Siever 1979; Saigal et al. 1988; Morad et al. 1990). The presence of barite within altered feldspars (e.g., in TSU-3) may be the result of derivation of barium from albitization of Kfeldspar (Ali and Turner 1982; Long and Luth 1986; Kastner and Siever 1979). $\mathrm{Al}^{3+}$ and $\mathrm{Ca}^{2+}$, by-products of plagioclase albitization, may be precipitated in carbonates relatively easily under the $\mathrm{pCO}_{2}$ levels present in most basins (Boles 1982; Morad et al. 1990), consistent with the presence of abundant calcite cement in the siliciclastic sandstones and in the hybrid arenites.

\section{VI.4. Evolution of Reservoir Quality}

Scarce early diagenetic calcite and dolomite cements rendered the hybrid arenites and sandstones sensitive to mechanical compaction, which resulted in significant porosity destruction during eogenesis (cf. De Souza et al. 1995). The relatively low intergranular volume data (Table 1) reflect that the arenites suffered from significant compaction prior to cementation (cf. Paxton et al. 2002). The higher amounts of mechanically stable quartz grains in the sandstones resulted in less pervasive mechanical compaction, and thus preserved higher intergranular volume compared to the hybrid arenites (cf. Bloch et al. 2002). Porosity loss in the sandstones is interpreted to have occurred mainly by chemical compaction, i.e., intergranular pressure dissolution along quartz-quartz grain boundaries, and by concomitant cementation by syntaxial quartz overgrowths (cf. Fontana et al. 1989). The presence of dominantly point contacts between grains engulfed by poikilotopic ferroan calcite cement suggests relatively early precipitation of this cement. The presence of various types of grain contacts (point, straight, and sutured) and various intergranular volumes within intergranular ferroan calcite cement suggest precipitation during progressive burial and concomitant mechanical and chemical compaction (Machent et al. 2007). Several authors have concluded that pressure dissolution of quartz grains is enhanced by a considerable increase in burial depth (i.e., increase in effective stress), temperature, and time $\left(>3 \mathrm{~km},>90^{\circ} \mathrm{C}\right.$; Oelkers et al. 1996; Sheldon et al. 2003), whereas the onset of pressure dissolution of carbonate grains has been suggested to occur at burial depths less than ca. 1500 m (Buxton and Sibley 1981; Saller 1984). Carbonate pressure dissolution has acted as a source of burial carbonate cements in the studied rocks.

Secondary porosity is rare in the siliciclastic and hybrid arenites and has resulted mainly from the dissolution of coarsely crystalline, intergranular calcite cement and carbonate grains. Dissolution of calcite cement and pressure dissolution of carbonate grains indicate that the diagenetic evolution of these deposits has involved considerable cement redistribution (Dutton and Barton 2001). The extremely low porosity and permeability of sandstones and hybrid arenites from this foreland basin (Ketzer and Morad 2006) make them suitable only for gas rather than oil reservoirs. However, porosity and permeability in such reservoirs can be generated by tectonic fracturing (Camara et al. 1988; Díaz Merino et al. 2006). 
This study thus reveals that the diagenetic evolution of turbiditic arenites of foreland basins follow various diagenetic evolution pathways, which can induce considerable variation in the spatial and temporal distribution of reservoir quality and heterogeneity. Sandstones rich in mechanically stable quartz grains have been subjected to slower rates of porosity loss than arenites rich in ductile extrabasinal and intrabasinal carbonate grains (Bloch et al. 2002; Paxton et al. 2002). Moreover, these carbonate grains act as sites for nucleation and growth of carbonate cement, and hence contribution to the greater rates of porosity loss than the quartz-rich sandstones (Buxton and Sibley 1981; Saller 1984).

\section{Conclusions}

Petrological and geochemical study of marine foreland basin turbiditic hybrid arenites and sandstones of the Hecho Group (Eocene), southcentral Pyrenees, Spain, reveals that diagenetic evolution pathways are closely linked to the variation in detrital composition, particularly the proportions and types of extrabasinal noncarbonates, extrabasinal carbonates, and intrabasinal carbonate grains. Important results include:

Marine turbiditic hybrid arenites are subjected to more rapid and extensive porosity loss owing to more compaction and cementation in these than in siliciclastic sandstones in the same succession. Total elimination of reservoirs quality makes the hybrid arenites and sandstones suitable only as tight gas reservoirs dominated by microporosity.

* Hybrid arenites are cemented extensively by mesogenetic carbonates (calcite, dolomite, and trace amounts of siderite). The low $\delta^{i 8} \mathrm{O}$ values of the intergranular calcite cement $(-10.0 \%$ o to $-5.8 \%$ o) coupled with the high salinity (mode $=18.8$ wt \% eq. $\mathrm{NaCl}$ ) and $\mathrm{T}_{\mathrm{h}}\left(\right.$ mode $\left.=80^{\circ} \mathrm{C}\right)$ of fluid inclusions suggest involvement of basinal saline fluids sourced from the underlying Upper Triassic evaporitic deposits. The low $\delta^{\mathrm{i} 8} \mathrm{O}_{\mathrm{v}-\mathrm{PDB}}$ values of the Fe-dolomite $\left(\delta^{\mathrm{i} 8 \mathrm{O}}=-8.5 \%\right.$ o to $-6.3 \%$ o) suggest continuous precipitation during progressive burial and increasing temperatures, sourced mainly from pressure dissolution of intrabasinal and extrabasinal carbonate grains.

* The siliciclastic sandstones in the deepest tectonostratigraphic unit are characterized by the dominance of quartz grains, which prevented substantial porosity loss by mechanical compaction. Mesogenetic processes affecting the reservoir quality included quartz cementation, calcite and dolomite cementation, and chemical compaction (i.e., intergranular pressure dissolution of quartz grains). The well-lithified sandstones were brittle, favoring the development of fracture porosity and permeability during tectonic deformation.

* Diagenetic alterations common to hybrid arenites and siliciclastic sandstones, such as pyrite precipitation, intragranular calcite cementation, and albitization, which are not extensive, had no effect on reservoir quality.

* The formation of vein saddle calcite with $\delta^{8} \mathrm{O}_{\mathrm{v}-\text {-р⿱一土㇒ }}$ values from $-10.4 \%$ o to $-7.8 \%$ o and

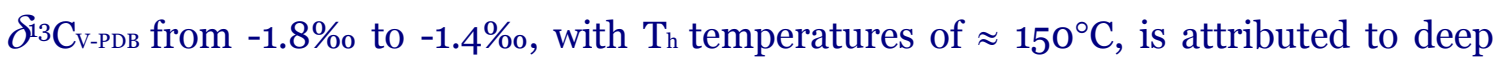
circulation of hot meteoric waters during fracturing associated with the extensional stage of tectonism in the foreland basin.

* These results illustrate that proper understanding of the spatial and temporal distribution of reservoir-quality evolution in marine turbiditic arenite successions should be based on an integrated approach that links, primarily, diagenesis to variations in composition of primary framework grains. The diagenetic evolution pathways likely are not unique to this succession, and may thus provide insights into patterns of diagenesis in other foreland-basin successions. 


\section{Acknowledgments}

This work was accomplished within the framework of the EUROMARGIN project (o1-LECEMA10F), which was launched by the European Science Foundation and funded by the research councils of Spain, France, Italy, Norway, and Sweden. M.A. Caja and R. Marfil thank the CCGo7-UCM/AMB-2299 and CGL2006-01861 projects for partial financial support.Special thanks go to A. Permanyer for his help with vitrinite reflectance analyses. We are also very grateful for the assistance with thin-section preparation to M. Barajas and J. Estupiñan. Thanks go also to A. Fernández-Larios for his help with the electron microprobe analyses. This paper benefited significantly from comments made by JSR Editor, G. Rankey, and Associate Editors R. Worden and L.F. De Ros, and reviewers J. Gérard, D. Fontana, S. Patxon, and an anonymous reviewer.

\section{References}

AAGAARD, P., BJØRLYKKE, K., EGEBERG, P.K., SAIGAL, G.C., AND MORAD, S., 1990, Diagenetic albitization of detrital K-feldspars in Jurassic, Lower Cretaceous, and Tertiary clastic reservoir rocks from offshore Norway, II. Formation water chemistry and kinetic considerations: Journal of Sedimentary Petrology, v. 6o, p. 575-581.

AL-AASM, I.S., TAYLOR, B.E., AND SOUTH, B., 1990, Stable isotope analysis of multiple carbonate samples using selective acid extraction: Chemical Geology, v. 8o, p. 119-125.

ALI, A.D., AND TURNER, P., 1982, Authigenic K-feldspar in the Bromsgrove Sandstone Formation (Triassic) of Central England: Journal of Sedimentary Petrology, v. 52, p. 187-197.

AQRAWI, A.A.M., KERAMATI, M., EHRENBERG, S., PICKARD, N., MOALLEMI, A., SVA NA, T., DARKE, G., DICKSON, J.A.D., AND OXTOBY, N.H., 2006, The origin of dolomite in the Asmari Formation (Oligocene-lower Miocene), Dezful embayment, SW Iran: Journal of Petroleum Geology, v. 29, p. 381-402.

BAKKE, K., GJELBERG, J., AND AGERLIN, S., 2008, Compound seismic modelling of the Aínsa II turbidite system, Spain: application to deep-water channel systems offshore Angola: Marine and Petroleum Geology, v. 25, p. 1050-1085, DOI: 10.1016/ j.marpetgeo.2007.10.009.

BARKER, C.E., AND PAWLEWICZ, M.J., 1994, Calculation of vitrinite reflectance from thermal histories and peak temperatures, in Mukhopadhyay, P.K., and Dow, W.G., eds., Vitrinite Reflectance as a Maturity Parameter: Applications and Limitations, American Chemical Society, Symposium Series, no. 570, p. 216-229.

BITZER, K., TRAVÉ, A., AND CARMONA, J.M., 2001, Fluid flow processes at basin scale: Acta Geologica Hispanica, v. 36, p. 1-20.

BLOCH, S., 1994, Effect of detrital mineral composition on reservoir quality, in Wilson, M.D., ed., Reservoir Quality Assessment and Prediction in Clastic Rocks, SEPM, Short Course Notes 30, p. 161-182.

BLOCH, S., LANDER, R.H., AND BONNELL, L., 2002, Anomalously high porosity and permeability in deeply buried sandstone reservoirs: origin and predictability: American Association of Petroleum Geologists, Bulletin, v. 86, p. 301-328.

BODEGO, A., AND AGIRREZABALA, L.M., 2007, Albian sediment-filled fissures on an Urgonian carbonate platform as kinematic indicators of extension, Westernmost Pyrennes: Geogaceta, v. 41, p. 27-34.

BOLES, J.R., 1982, Active albitization of plagioclase, Gulf Coast Tertiary: American Journal of Science, v. 282, p. 165-180.

BUXTON, T.M., AND SIBLEY, D.F., 1981, Pressure solution features in a shallow buried limestone: Journal of Sedimentary Petrology, v. 51, p. 19-26.

CAJA, M.A., MARFIL, R., GARCIA, D., REMACHA, E., MANSURBEG, H., MORAD, S., AND AMOROSI, A., 2007, Provenance and reservoir quality of carbonate-rich turbiditic arenites from the Hecho Group, South Central Pyrenees, Spain: General Assembly of the 
European Geosciences Union (EGU), Vienna, Austria: Geophysical Research Abstracts, v. 9, $01738 \mathrm{p}$.

CAMARA, P., RODRÍGUEZ dE PEDRO MORENO, J., AND MORENO, J.M., 1988, Serrablo gas field: An example of trap in syntectonic brecciated reservoir, Pyrenees (Spain) (abstract): American Association of Petroleum Geologists, Bulletin, v. 72, 993 p.

DE ROS, L.F., AND GOLDBERG, K., 2007, Reservoir petrofacies: a tool for quality characterization prediction: American Association of Petroleum Geologists, Annual Convention and Exhibition, Long Beach, CA, p. 1-6.

DE SOUZA, R.S., DE ROS, L.F., AND MORAD, S., 1995, Dolomite diagenesis and porosity preservation in lithic reservoirs: Carmópolis Member, Sergipe-Alagoas Basin, northeastern Brazil: American Association of Petroleum Geologists, Bulletin, v. 79, p. 725-748.

DÍAZ MERINO, C., VICENTE BRAVO, J.C., VILLALBOS, L., LEÓN, L., CÁMARA, P., AND MARTÍNEZ DEL OLMO, W., 2006, The Serrablo field, a commercial gas discovery in the Jaca basin (southern Pyrenees, Spain), in Martínez del Olmo, W., ed., XXV Aniversario Asociación de Geólogos y Geofísicos Españoles del Petróleo, p. 131-146.

DICKINSON, W.R., 1984, Interpreting provenance relations from detrital modes of sandstones, in Zuffa, G.G., ed., Provenance of Arenites, NATO Advanced Science Institutes, Series C 148, p. 333-361.

DICKINSON, W.R., AND SUCZEK, C.A., 1979, Plate tectonics and sandstone compositions: American Association of Petroleum Geologists, Bulletin, v. 63, p. 2164-2182.

DICKINSON, W.R., AND VALLONI, R., 1980, Plate settings and provenance of sands in modern ocean basins: Geology, v. 8, p. 82-86.

DICKINSON, W.R., BEARD, S.L., BRAKENRIDGE, G.R., ERJAVEC, J.L., FERGUSON, R.C., INMAN, K.F., KNEPP, R.A., LINDBERG, F.A., AND RYBERG, P.T., 1983, Provenance of North American sandstones in relation to tectonic setting: Geological Society of America, Bulletin, v. 94, p. 222-235.

DOS ANJOS, S.M.C., DE ROS, L.F., SCHIFFER DE SOUZA, R., ASSIS SILVA, C.M., AND SOMBRA, C.L., 2000, Depositional and diagenetic controls on the reservoir quality of Lower Cretaceous Pendencia sandstones, Potiguar rift basin, Brazil: American Association of Petroleum Geologists, Bulletin, v. 84, p. 1719-1742.

DUTTON, S.P., 2008, Calcite cement in Permian deep-water sandstones, Delaware Basin, West Texas: Origin, distribution, and effect on reservoir properties: American Association of Petroleum Geologists, Bulletin, v. 92, p. 765-787.

DUTTON, S.P., AND BARTON, M.D., 2001, Diagenesis and reservoir quality of turbidite andstones in the Bell Canyon Formation, Delaware Basin, Texas: Geological Society of America, Abstracts with Programs, v. 33, p. 36-37.

EL-GHALI, M., MORAD, S., AL-AASM, I.S., AND RAMSEYER, K., 2006, Distributions of diagenetic alterations in glaciogenic sandstones within depositional facies and sequence stratigraphic framework: evidence from Upper Ordovician of the Murzuq Basin, SW Libya: Sedimentary Geology, v. 190, p. 323-351.

FALIVENE, O., CABRERA, L., MUÑOZ, J.A., ARBUÉS, P., FERNÁNDEZ, O., AND SÁEZ, A., 2007, Statistical grid-based facies reconstruction and modelling for sedimentary bodies. Alluvial-palustrine and turbiditic examples: Geologica Acta, v. 5, p. 199-230.

FERKET, H., SWENNEN, R., ORTUÑO-ARZATE, S., CACAS, M.C., AND ROURE, F., 2004, Vein formation in Cretaceous carbonates in the Laramide foreland fold and thrust belt of eastern Mexico, in Swennen, R., Roure, F., and Granath, J.W., eds., Deformation, fluid flow, and reservoir appraisal in foreland fold and thrust belts, American Association of Petroleum Geologists, Hedberg Series, no. 1, p. 133-156.

FONTANA, D., ZUFFA, G.G., AND GARZANTI, E., 1989, The interaction of eustacy and tectonism from provenance studies of the Eocene Hecho Group turbidite complex (South-Central Pyreneees, Spain): Basin Research, v. 2, p. 223-237.

FROELICH, P.N., KLINKHAMMER, G.P., BENDER, M.L., LUEDTKE, N.A., HEATH, G.R., CULLEN, D., DAUPHIN, P., HAMMOND, D., HARTMAN, B., AND MAYNARD, V., 
1979, Early oxidation of organic matter in pelagic sediments of the eastern equatorial Atlantic: suboxic diagenesis: Geochimica et Cosmochimica Acta, v. 43, p. 1075-1090.

GARCIA, D., CAJA, M.A., MARFIL, R., REMACHA, E., MANSURBEG, H., MORAD, S., AND AMOROSI, A., 2007, K-feldspar albitization in the Hecho Group turbidites (southcentral Pyrenean Basin, Spain) and fluid-rock exchange models: General Assembly of the European Geosciences Union (EGU), Vienna, Austria: Geophysical Research Abstracts, v. 9, 06007 p.

HENDRY, J.P., WILKINSON, M., FALLICK, A.E., AND TREWIN, N.H., 200o, Disseminated "jigsaw piece" dolomite in Upper Jurassic shelf sandstones, Central North Sea: an example of cement growth during bioturbation?: Sedimentology, v. 47, p. 631-644.

JONES, R.W., PICKERING, K.T., BOUDAGHER-FADEL, M., AND MATTHEWS, S., 2005, Preliminary observations on the micropalaeontological characterization of submarine fan/channel sub-environments, Aínsa System, south-central Pyrenees, Spain, in Powell, A.J., and Riding, J.B., eds., Recent Developments in Applied Biostratigraphy, The Micropalaeontological Society, Special Publication TMSoo1, p. 55-68.

KANTOROWICZ, J.D., BRYANT, I.D., AND DAWANS, J.M., 1987, Controls on the geometry of carbonate cements in Jurassic sandstones: Bridport Sands, southern England and Viking Group, Troll Field, Norway, in Marshall, R., ed., Diagenesis of Sedimentary Sequences, Geological Society of London, Special Publication 36, p. 103-118.

KASTNER, M., AND SIEVER, R., 1979, Low temperature feldspars in sedimentary rocks: American Journal of Science, v. 279, p. 435-479.

KENDALL, A.C., 1985, Radiaxial fibrous calcite: a reappraisal, in Schneidermann, N., and Harris, P.M., eds., Carbonate Cements, SEPM, Special Publication 35, p. 59-77.

KETZER, J.M., AND MORAD, S., 2006, Predictive distribution of shallow marine, lowporosity (pseudomatrix-rich) sandstones in a sequence stratigraphic frameworkexample from the Ferron sandstone, Upper Cretaceous, USA: Marine and Petroleum Geology, v. 23, p. 29-36.

KETZER, J.M., MORAD, S., EVANS, R., AND AL-AASM, I.S., 2002, Distribution of diagenetic alterations in fluvial, deltaic, and shallow marine sandstones within a sequence stratigraphic framework: evidence from the Mullaghmore Formation (Carboniferous), NW Ireland: Journal of Sedimentary Research, v. 72, p. 760-774.

KETZER, J.M., MORAD, S., AND AMOROSI, A., 2003, Predictive diagenetic clay-mineral distribution in siliciclastic rocks within a sequence stratigraphic framework, in Worden, R.H., and Morad, S., eds., Clay Mineral Cements in Sandstones, International Association of Sedimentologists, Special Publication 34, p. 43-61.

LABOURDETTE, R., CRUMEYROLLE, P., AND REMACHA, E., 2008, Characterisation of dynamic flow patterns in turbidite reservoirs using 3D outcrop analogues: Example of the Eocene Morillo turbidite system (South-central Pyrenees, Spain): Marine and Petroleum Geology, v. 25, p. 255-270, doi: 10.1016/j.marpetgeo.2007.07.003.

LAND, L.S., 1983, The application of stable isotopes to studies of the origin of dolomite and to problems of diagenesis of clastic sediments, in Arthur, M.A., and Anderson, T.F., eds., Stable Isotopes in Sedimentary Geology, SEPM, Short Course 10, p.4.1-4.22.

LAWTON, T.F., 1986, Compositional trends within a clastic wedge adjacent to a foldthrust belt: Indianola Group, central Utah, U.S.A, in Allen, P.A., and Homewood, P., eds., Foreland Basins, International Association of Sedimentologists, Special Publication 8, p. 411-423.

LONG, P.E., AND LUTH, W.C., 1986, Origin of K-feldspar megacrystals in granitic rocks:Implications of a partitioning model for barium: American Mineralogist, v. 71, p.367-375.

MACHENT, P.G., TAYLOR, K.G., MACQUAKER, J.H.S., AND MARSHALL, J.D., 2007, Patterns of early post-depositional and burial cementation in distal shallow-marine sandstones: Upper Cretaceous Kenilworth Member, Book Cliffs, Utah, USA: Sedimentary Geology, v. 198, p. 125-145. 
MANSURBEG, H., 2007. Diagenesis and reservoir-quality evolution of deep-water turbidites: links to basin setting, depositional facies, and sequence stratigraphy [Unpublished Ph.D. Thesis]: Uppsala University, 58 p.

MANSURBEG, H., MORAD, S., SALEM, A., MARFIL, R., EL-GHALI, M.A.K., NYSTUEN, J.P., CAJA, M.A., AMOROSI, A., GARCIA, D., AND LA IGLESIA, A., 2008, Diagenesis and reservoir quality evolution of Palaeocene deepwater, marine sandstones, the Shetland-Faroes Basin, the British continental shelf: Marine and Petroleum Geology, v. 25, p. 514-543, doi: 10.1016/j.marpetgeo.2007.07.012.

MARFIL, R., CAJA, M.A., TSIGE, M., AL-AASM, I.S., MARTI'N-CRESPO, T., AND SALAS, R., 2005, Carbonate-cemented stylolites and fractures in the Eastern Iberian Range, Spain: A record of palaeofluids composition and thermal history: Sedimentary Geology, v. 178, p. 237-257.

MARFIL, R., MANSURBEG, H., GARCIA, D., CAJA, M.A., REMACHA, E., MORAD, S., AND AMOROSI, A., in press, Dolomite-rich condensed sections in the overbank of turbidite channels, Eocene Hecho Group (South-central Pyrenees, Spain), in Morad, S., and Ketzer, M., eds., Linking Diagenesis and Sequence Stratigraphy, International Association of Sedimentologists, Special Publication.

MOORE, C.H., 1989. Carbonate diagenesis and porosity: Amsterdam, Elsevier, Developments in Sedimentology, no. 46. Elsevier, 338 p.

MORAD, S., 1986, Albitization of K-feldspar grains in Proterozoic arkoses and greywackes from southern Sweden: Neues Jahrbuch für Mineralogie, v. 4, p. 145-156.

MORAD, S., 1998, Carbonate cementation in sandstones: distribution patterns and geochemical evolution, in Morad, S., ed., Carbonate cementation in sandstones, International Association of Sedimentologists, Special Publication 26, p. 1-26.

MORAD, S., BERGEN, M., KNARUD, R., AND NYSTUEN, J.P., 1990, Albitization of detrital plagioclase in Triassic reservoir sandstones from the Snorre field, Norwegian North Sea: Journal of Sedimentary Petrology, v. 60, p. 411-425.

MORAD, S., KETZER, J.M., AND DE ROS, L.F., 2000, Spatial and temporal distribution ofdiagenetic alterations in siliciclastic rocks: implications for mass transfer in sedimentary basins: Sedimentology, v. 47, p. 95-120.

MUÑOZ, J.A., 1992, Evolution of a continental collision belt: ECORS-Pyrenees crustal balanced cross section, in McClay, K.R., ed., Thrust Tectonics: London, Chapman \& Hall, p. 235-246.

MUTTI, E., LUTERBACHER, H.P., FERRER, J., AND ROSELL, J., 1972, Schema estratigrafico e lineamenti di facies del Paleogene marino della zona centrale sudpirenaica tra Tremp (Catalogna) e Pamplona (Navarra): Societa Geologica Italiana, Memorie 11, p. 391-416.

MUTTI, E., REMACHA, E., SGAVETTI, M., ROSELL, J., VALLONI, R., AND ZAMORANO, M., 1985a, Stratigraphy and facies characteristics of the Eocene Hecho Group turbidite systems, south-central Pyrenees, in Mila, M.D., and Rosell, J., eds., Excursion Guidebook of the 6th European Regional Meeting, International Association of Sedimentologists, Lleida, Spain, p. 519-576.

MUTTI, E., SEGURES, M., AND SGAVETTI, M., 1988, Sedimentation and deformation in the Tertiary sequences of the southern Pyrenees: Field trip 7 guidebook, American Association of Petroleum Geologists, Mediterranean Basin Conference, Nice, France:Special Publication of the Institute of Geology of the University of Parma, $157 \mathrm{p}$.

MUTTI, E., TINTERRI, R., REMACHA, E., MAVILLA, N., ANGELLA, S., AND FAVA, L., $1985 \mathrm{~b}$, An introduction to the analysis of ancient turbidite basins from an outcrop perspective: American Association of Petroleum Geologists, Continuing Education Course Notes Series 39, 61 p.

NAGTEGAAL, P.J.C., 1978, Sandstone framework instability as a function of burial diagenesis: Geology Society of London, Journal, v. 135, p. 101-106. 
OELKERS, E.H., BJØRKUM, P.A., AND MURPHY, W.M., 1996, A petrographic and computational investigation of quartz cementation and porosity reduction in North Sea sandstones: American Journal of Science, v. 206, p. 420-452.

PAXTON, S.T., SZABO, J.O., AJDUKIEWICZ, J.M., AND KLIMENTIDIS, R.E., 2002, Construction of an intergranular volume compaction curve for evaluating and predicting compaction and porosity loss in rigid-grain sandstone reservoirs: American Association of Petroleum Geologists, Bulletin, v. 86, p. 2047-2067.

PETTIJOHN, F.J., POTTER, P.E., AND SIEVER, R., 1972. Sand and Sandstone: Berlin, Springer-Verlag, $617 \mathrm{p}$.

PITTMAN, E.D., AND LARESE, R.E., 1991, Compaction of lithic sands: experimental results and aplications: American Association of Petroleum Geologists, Bulletin, v. 75, p. 12791299.

RAISWELL, R., 1997, A geochemical framework for the application of stable sulphur isotopes to fossil pyritization: Geological Society of London, Journal, v. 154, p.343-356.

REMACHA, E., OMS, O., AND COELLO, J., 1995, The Rapitán turbidite channel and its related eastern levee-ovebank deposits, Eocene Hecho group, south-central Pyrenees, Spain, in Pickering, K.T., Hiscott, R.N., Kenyon, N.H., Ricci Lucchi, F., and Smith, R.D.A., eds., Atlas of Deep Water Environments: Architectural Style in Turbidite Systems: London, Chapman \& Hall, p. 145-149.

REMACHA, E., GUAL, G., BOLAÑO, F., ARCURI, M., OMS, O., CLIMENT, F., CRUMEYROLLE, P., FERNÁNDEZ, L.P., VICENTE, J.C., AND SUÁREZ, J., 2003, Sand-rich turbidite systems of the Hecho Group from slope to the basin plain: facies, stacking patterns, controlling factors and diagnostic features: American Association of Petroleum Geologists, International Conference and Exhibition, Barcelona, Spain, September 21-24. Geological Field Trip no. 12, South-Central Pyrenees.

REMACHA, E., FERNÁNDEZ, L.P., AND MAESTRO, E., 2005, The transition between sheetlike lobes and basin plain turbidites in the Hecho Group (South-central Pyrenees, Spain): Journal of Sedimentary Research, v. 75, p. 798-819.

SAIGAL, G.C., AND BJØRLYKKE, K., 1987, Carbonate cements in clastic reservoir rocks from offshore Norway-relationships between isotopic composition, textural development and burial depth, in Marshall, J.D., ed., Diagenesis of Sedimentary Sequences, Geological Society of London, Special Publication 36, p. 313-324.

SAIGAL, G.C., MORAD, S., BJØRLYKKE, K., EGEBERG, P.K., AND AAGAARD, P., 1988, Diagenetic albitization of detrital K-feldspar in Jurassic, Lower Cretaceous, and Tertiary clastic reservoir rocks from offshore Norway, I. Textures and origin: Journal of Sedimentary Petrology, v. 58, p. 1003-1013.

SALLER, A.H., 1984, Petrologic and geochemical constraints on the origin of subsurface dolomite, Enewetok Atoll: An example of dolomitization by normal seawater: Geology, v. 12, p. 217-220.

SCHIEBER, J., 2002, Sedimentary pyrite: A window into the microbial past: Geology, v. 30, p. 531-534.

SCHOLLE, P.A., 1971, Diagenesis of deep-water carbonate turbidites, Upper Cretaceous Monte Antola flysch, Northern Apennines, Italy: Journal of Sedimentary Petrology, v. 41, p. 233-250.

SCHWAB, F.L., 1986, Sedimentary "signature" of foreland basin assemblage: real or counterfeit?, in Allen, P.A., and Homewood, P., eds., Foreland Basins, International Association of Sedimentologists, Special Publication 8, p. 395-410.

SHACKLETON, N.J., AND KENNETH, D.J., 1975, Paleotemperature history of the Cenozoic and initiation of Antarctic glaciation: oxygen and carbon isotope analyses in DSDP sites 277, 279 and 289: Deep Sea Drilling Project, Interim Report 29, p. 743-755.

SHELDON, H.A., WHEELER, J., WORDEN, R.H., AND CHEADLE, M.J., 2003, Analysis of the roles of stress, temperature, and $\mathrm{pH}$ in chemical compaction of sandstones: Journal of Sedimentary Research, v. 73, p. 64-71. 
SOTO, R., AND CASAS, A.M., 2001, Geometriá y cinemática de las estructuras Norte-Sur de la Cuenca de Aínsa: Sociedad Geológica de España, Revista, v. 14, p. 199-211.

SOUTH, D.L., AND TALBOT, M.R., 2000, The sequence stratigraphic framework of carbonate diagenesis within transgressive fan-delta deposits: Sant Llorenc, del Munt fan-delta complex, SE Ebro Basin, NE Spain: Sedimentary Geology, v. 138, p. 179-198.

SPADAFORA, E., DE ROS, L.F., ZUFFA, G.G., MORAD, S., AND AL-AASM, I.S., 1998, Diagenetic evolution of synorogenic hybrid and lithic arenites (Miocene), northern Apennines, Italy, in Morad, S., ed., Carbonate Cementation in Sandstones, International Association of Sedimentologists, Special Publication 26, p. 241-260.

SPÖTL, C., AND PITTMAN, J.K., 1998, Saddle (baroque) dolomite in carbonates and sandstones: a reappraisal of a burial-diagenetic concept, in Morad, S., ed., Carbonate Cementation in Sandstones, International Association of Sedimentologists, Special Publication 26, p. 437-460.

TEIXELL, A., 1998, Crustal structure and orogenic material budget in the west central Pyrenees: Tectonics, v. 13, p. 395-406.

TOBIN, K.J., WALKER, K.R., STEINHAUFF, D.M., AND MORA, C.I., 1996, Fibrous calcite from the Ordovician of Tennessee: preservation of marine oxygen isotopic composition and its implications: Sedimentology, v. 43, p. 235-251.

TRAVÉ, A., LABAUME, P., CALVET, F., AND SOLER, A., 1997, Sediment dewatering and pore fluid migration along thrust faults in a foreland basin inferred from isotopic and elemental geochemical analyses (Eocene southern Pyrenees, Spain): Tectonophysics, v. 282, p. 375-398.

TUCKER, M.E., 1986, Formerly aragonitic limestones associated with tillites in the Late Proterozoic of Death Valley, California: Journal of Sedimentary Petrology, v. 56, p. 818830.

TUCKER, M.E., AND WRIGHT, P., 1990. Carbonate sedimentology: London, Blackwell Scientific Publications, 482 p.

VARLAMOFF, N., 1972, Central and West African rare-metal granitic pegmatites, related aplites, quartz veins and mineral deposits: Mineralium Deposita, v. 7, p. 202-216.

VILASI, N., SWENNEN, R., AND ROURE, F., 2006, Diagenesis and fracturing of PaleoceneEocene carbonate turbidite systems in the Ionian Basin: The example of the Kelçyra area (Albania): Journal of Geochemical Exploration, v. 89, p. 409-413.

WILKINSON, M., 1989, Discussion: evidence for surface reaction-controlled growth of carbonate concretions in shales: Sedimentology, v. 36, p. 951-953.

ZEEH, S., BECKER, H., AND HEGGEMANN, H., 2000, Dedolomitization by meteoric fluids: the Korbach fissure of the Hessian Zechstein basin, Germany: Journal of Geochemical Exploration, v. 69-70, p. 173-176.

ZUFFA, G.G., 1980, Hybrid arenites: their composition and classification: Journal of Sedimentary Petrology, v. 50, p. 21-29.

ZUFFA, G.G., 1985, Optical analysis of arenites: influence of methodology on compositional results, in Zuffa, G.G., ed., Provenance of Arenites, NATO ASI Series C, Reidel, Dordrecht, v. 148, p. 165-189.

ZURCHER, L., LOUNEJEVA, E., AND KRING, D.A., 2005, Preliminary analysis of relative abundances of hydrothermal alteration products in the C1-N10, C1-N10, Y6-N19, AND YAX-1_863.51 impact melt samples, Chicxulub structure, Mexico: Lunar and Planetary Science Conference XXXVI, Proceedings, p. 1-2. 


\section{Figures}

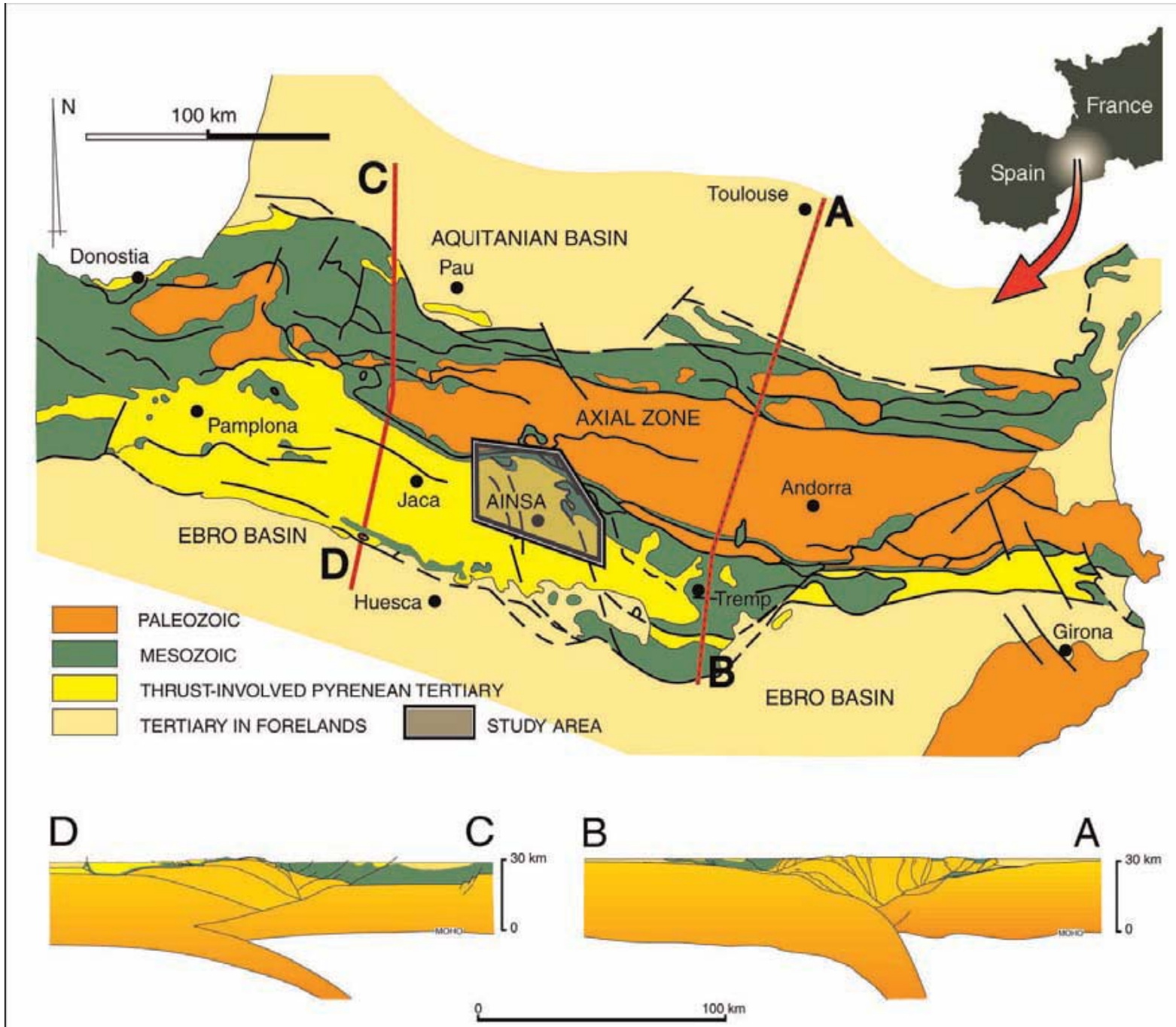

Figure 1: Highly simplified geological map of the Pyrenees showing location of both the study area and the cross sections included below (A-B and C-D). The lithosphere-scale balanced cross sections show the main structural features of the central Pyrenees, a fan-shaped delaminated orogenic wedge overlying the lower crust, related to the subduction of the Iberian crust beneath the Eurasian plate. Cross section A- B (from Muñoz 1992) accounts for field data and interpretation of the ECORS Pyrenees seismic survey. Cross section C-D (from Teixell 1998) is based on field work data and interpretation of the ECORS-Arzak seismic survey following the Veral transect to the south (Ansó valley). 


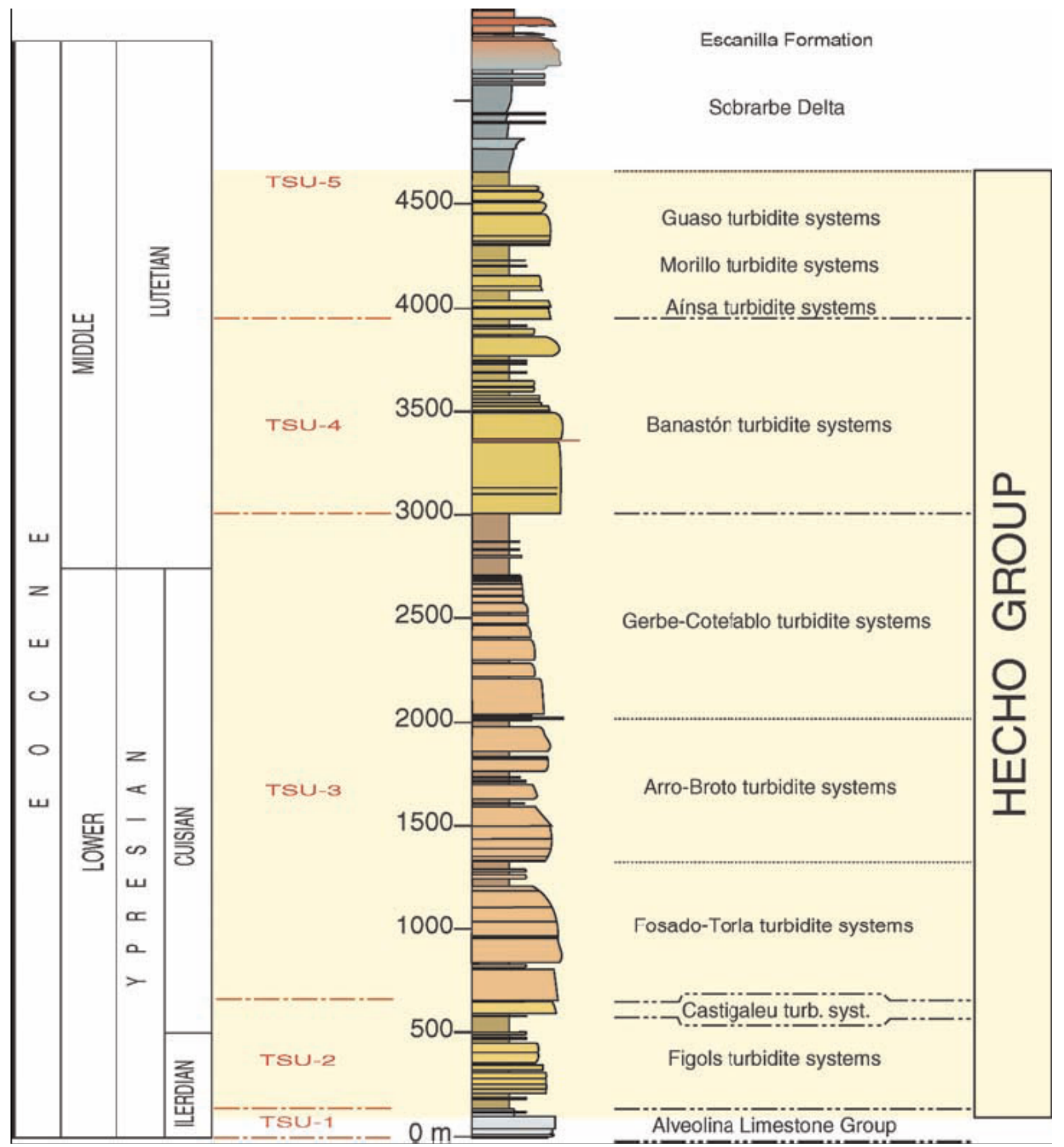

Figure 2: Composite stratigraphic column, mostly made along the Ara River valley, from Sierra Tendenera to Santa Maria del Buil, with chronostratigraphic reference for the TSUs and their component turbidite systems and nomenclature. The colors used in the different TSUs are subjective and do not have geological meaning. 


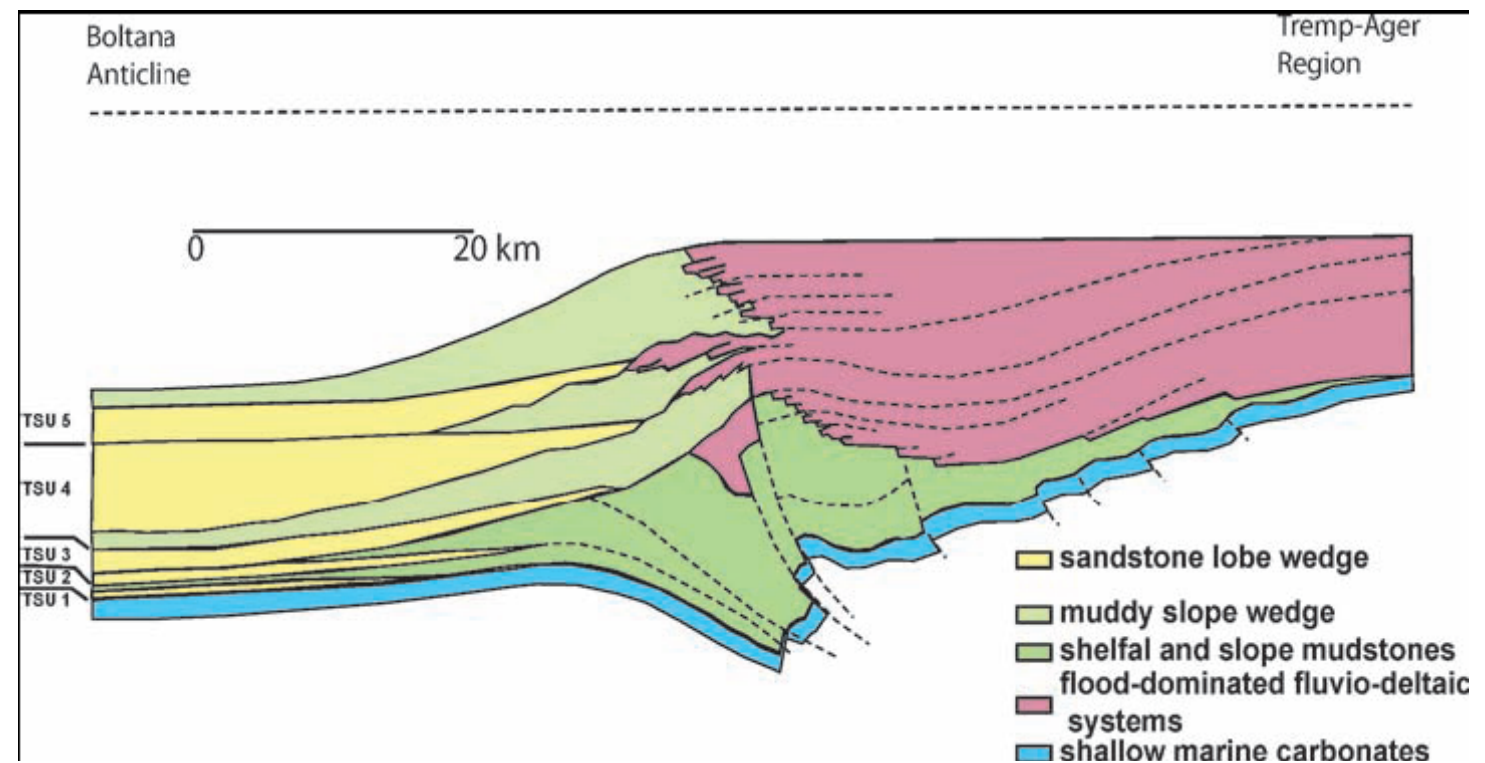

Figure 3: Schematic cross section of the eastern and central part of the Eocene foreland basin of the southcentral Pyrenees, Spain. See Figure 1 for location of Boltaña and Tremp- Ager regions. The stratigraphic section consists of five major unconformity-bounded units (TSUs; redrawn from Mutti et al. 1985, Mutti et al. 1988).

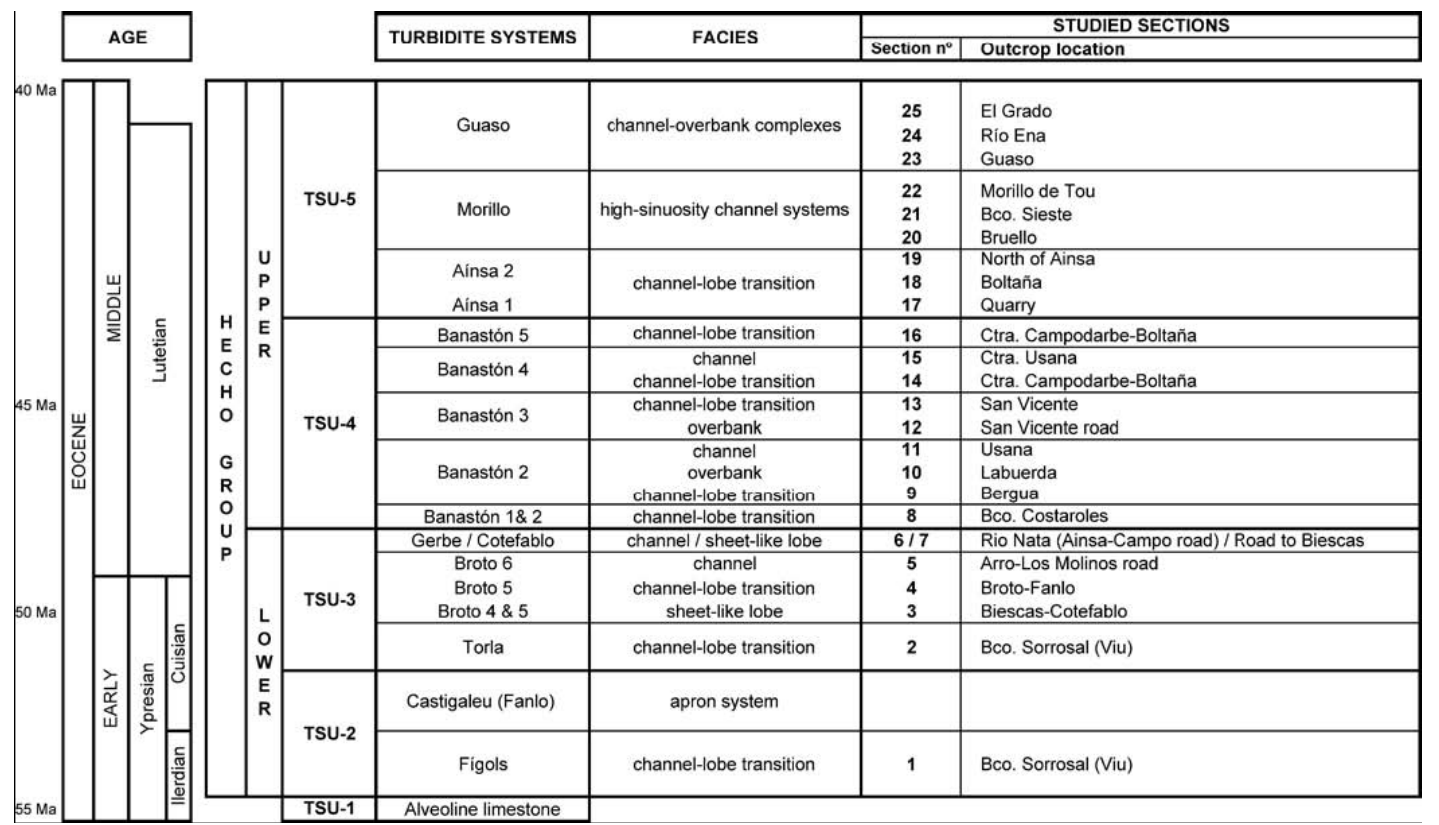

Figure 4: Chronostratigraphic succession of the turbidite system within the Hecho Group, showing the various tectonosedimentary units, the facies, and the studied sections.

Figure 5: Examples and field appearance of sampled outcrops of the Hecho Group. A) TSU-2, and B) lower TSU3 or Torla turbidite systems. Both outcrops are located in the Barranco del Sorrosal (west of the Boltaña anticline) and show strongly folded composite depositional sequences (third-order scale) with facies associations of sheetlike sandstone lobes (sandy stages of growth), transitionally overlain (to the left) by fine-grained and thin bedded mudstones (muddy stages of growth or slopedelta wedges). C) Overturned (top to the left) finingupward high-frequency facies cycle (fourth-order scale) of the Broto sheet sandstone lobes, within TSU-3, exposed along the road trenches between Broto and the Cotefablo pass (NW of the study zone). D) Sheet sands of the channel- lobe transition facies of TSU-4 (Banastón turbidite systems) in the San Vicente zone, north of the Hecho Group outcrop belt, located east of the Boltaña anticline (Aínsa Basin). E) Outcrops of the Barranco Forcaz, north of Aínsa, showing the Aínsa-2 turbidite systems, which are located in the lower part of the TSU-5, and showing channel- lobe transition facies association. F) Sand-rich high-sinuosity channels of the Morillo turbidite systems, within TSU-5, in the Barranco Sieste. 
International J ournal of Chemical Reactor Engineering, 2009, 7, A39

doi: 10.2202/ 1542-6580.1881
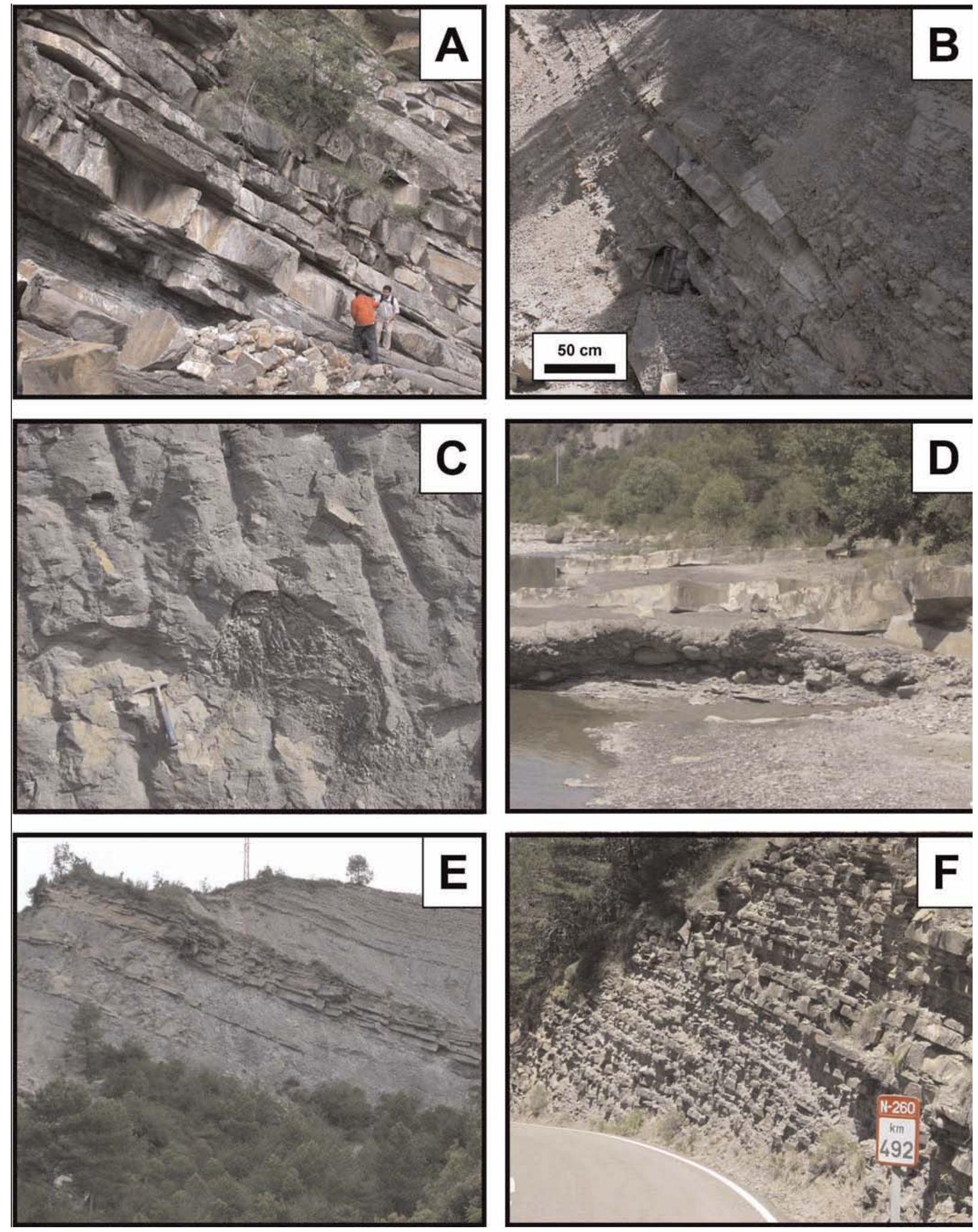




Figure 6: Compositional plots of the Hecho Group carbonate-rich arenites. Firstorder NCE-CE-CI classification (after Zuffa 1985), second-order, Q- F- L classification (after Pettijohn et al. 1972) and Q- F- L + CE classification. Note the increase in L + CE toward the TSU-5. The most characteristic facies of the studied units are: TSU-2, channel-lobe transition turbiditic arenites (Fígols); TSU-3, channels (Torla, Arro, and Gerbe), channel- lobe transition (Torla, Broto), and lobes (Cotefablo); TSU-4, canyon- channel transition, overbank deposits, and channel- lobe transition (Banastón 1 to 4); TSU-5, channel and channel- lobe transition (Aínsa 1 and 2), highsinuosity channel systems (Morillo), and channel- overbank complexes (Guaso).

Figure 7: Optical photomicrographs (cross-polarized light), cathodoluminescence images and BSE images showing: A, B) red luminescent intragranular calcite cement (TSU-5); the brighter luminescence observed is due to the presence of elevated Mn/Fe ratio. C, D) Dark-red luminescent intragranular calcite cement (TSU-5). E, F) Intragranular and intergranular calcite cement engulfing small crystals of pyrite. Note in Part E the presence of partially broken skeletal fossils by mechanical compaction, which predates the intergranular calcite cement. 
International J ournal of Chemical Reactor Engineering, 2009, 7, A39

doi: 10.2202/1542-6580.1881
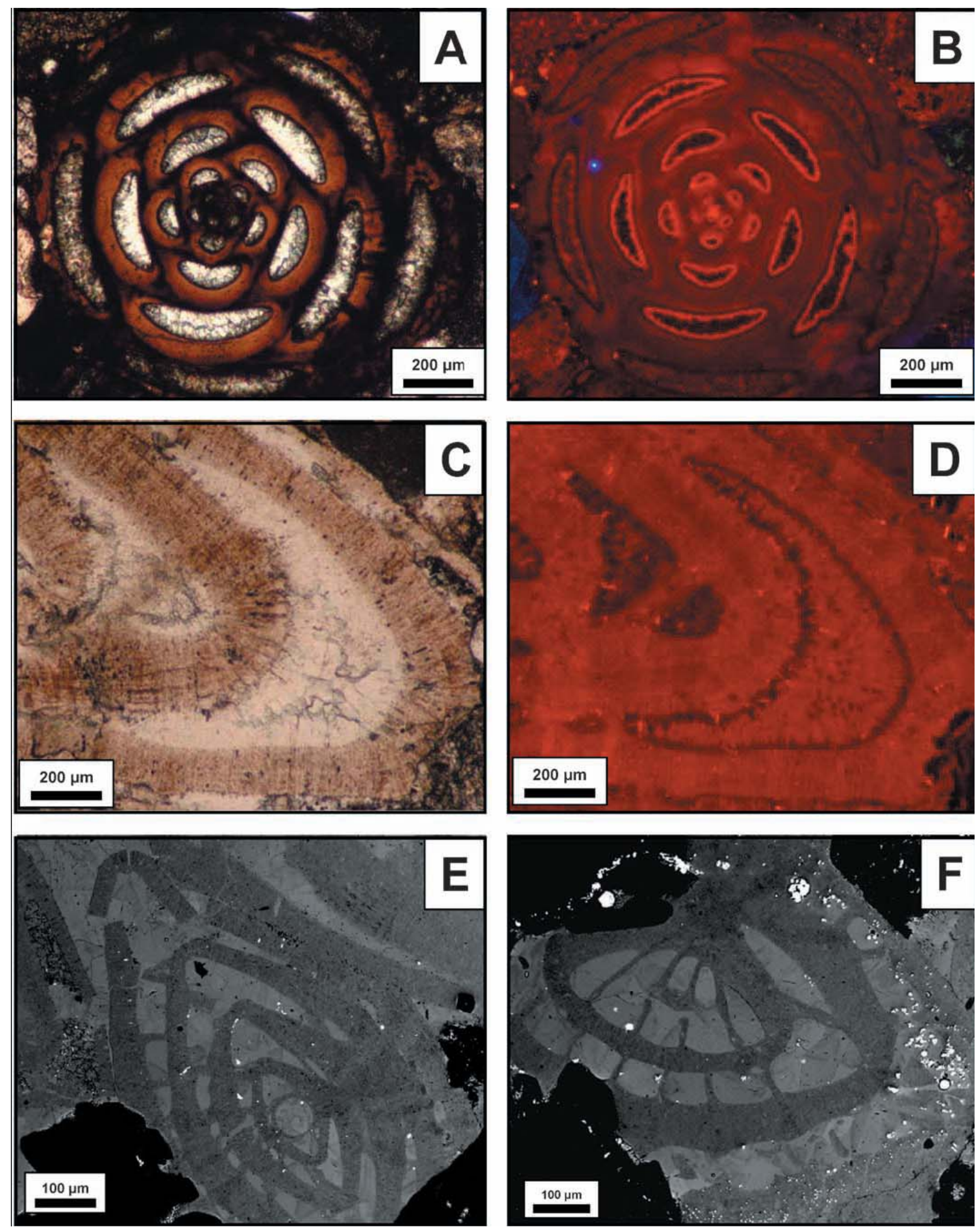




Figure 8: Cross plots of Fe versus Sr (TSU-2), and Fe versus Mn (TSU-3, TSU-4, and TSU-5) of calcite and dolomite cements showing the high Sr contents in fibrous calcite cement of TSU- 2 and the high Mn and Fe contents in the outer dolomite overgrowth compared to inner overgrowth.

Figure 9: Optical photomicrographs (cross-polarized light) and cathodoluminescence images showing: A, B) small dolomite crystals around the framework grains engulfed by the coarse mosaics of intergranular calcite cement. C, D) Dark-red to nonluminescent drusy crystals followed by red luminescent mosaic calcite crystals (TSU-5). E, F) nonluminescent to dark red luminescent calcite cement enclosing well rounded detrital carbonate grains (CE and CI), green and blue detrital plagioclase, and volcanic rock fragment in TSU-5 turbidites. 
International J ournal of Chemical Reactor Engineering, 2009, 7, A39

doi: 10.2202/1542-6580.1881
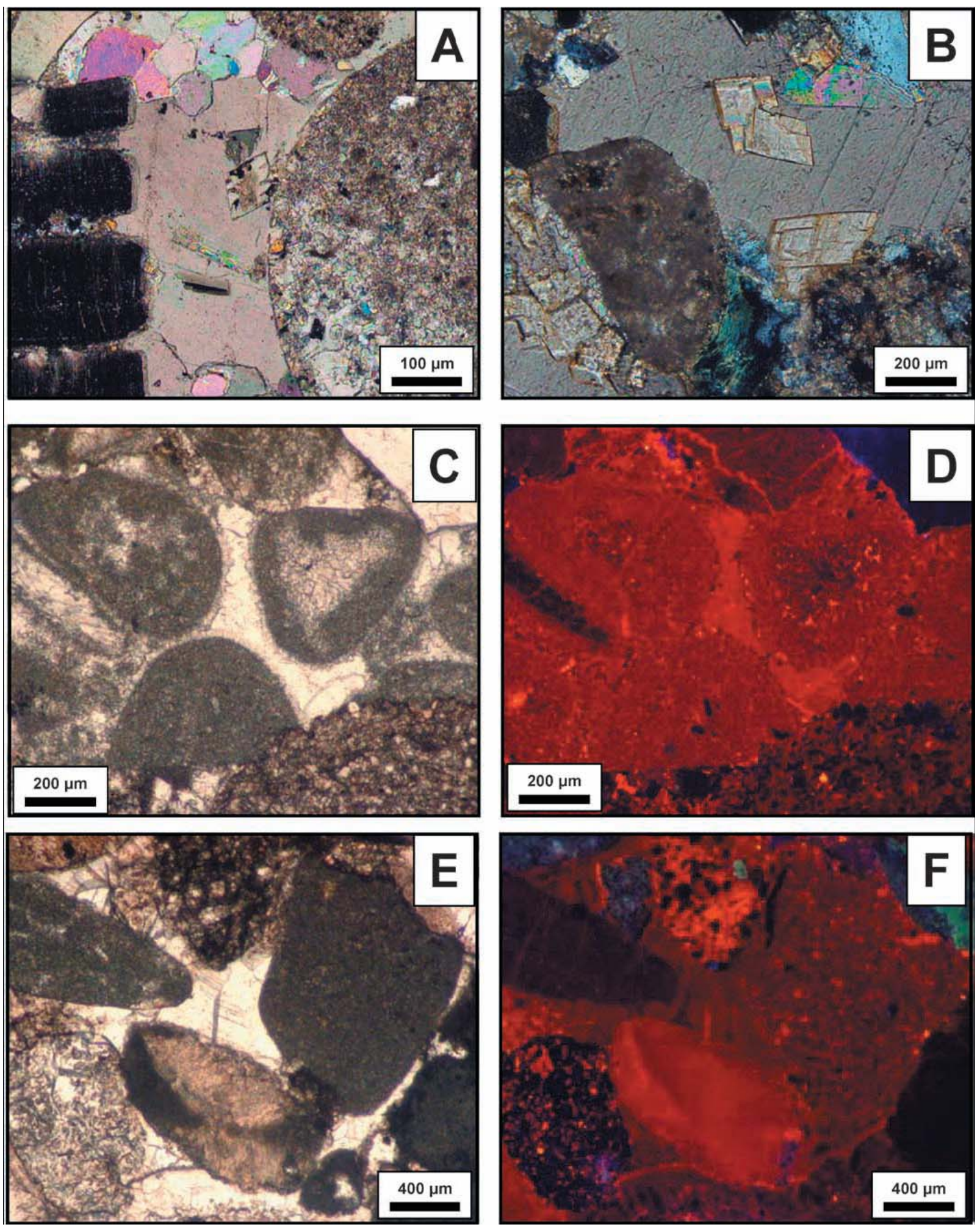

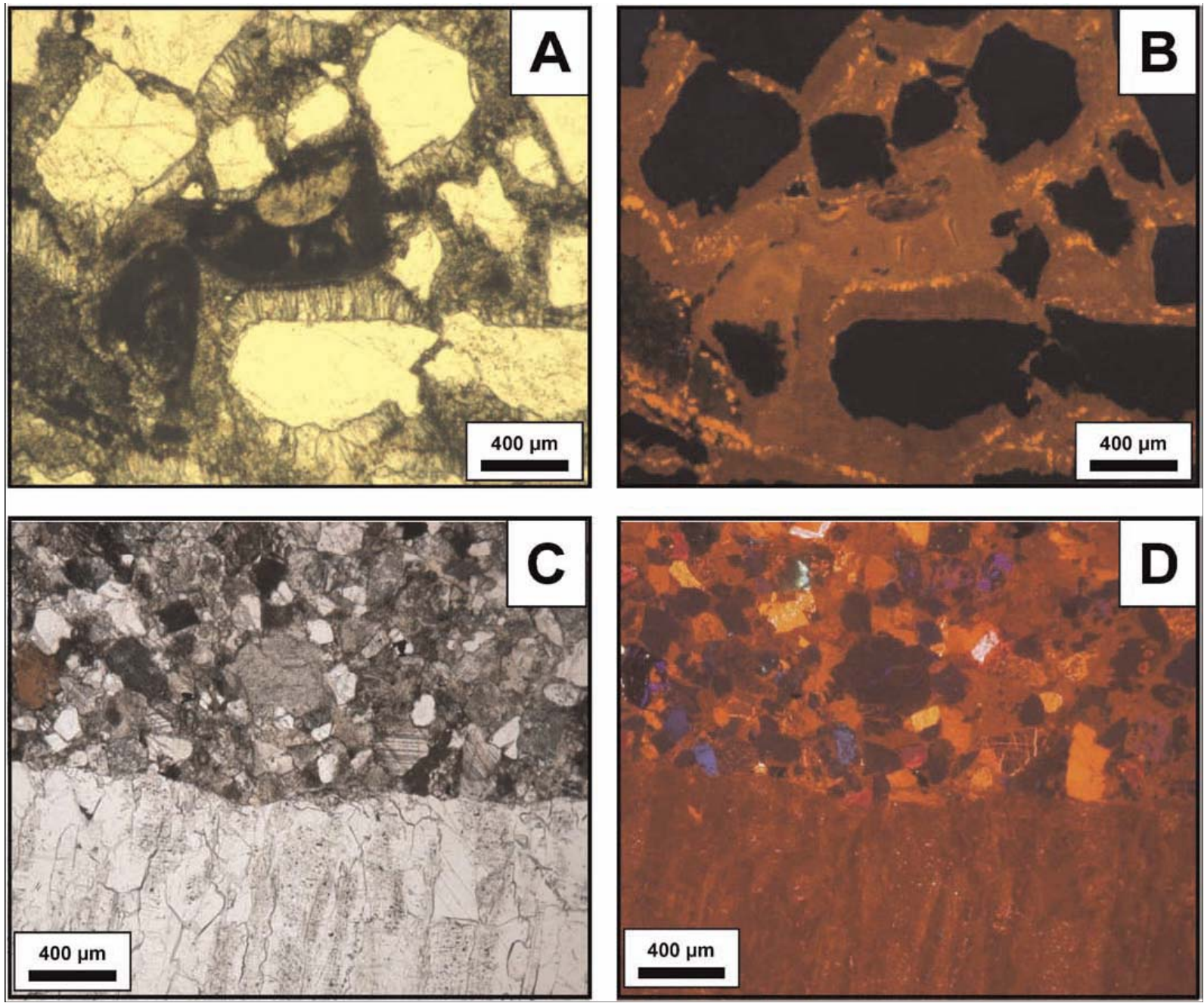

Figure 10: Optical photomicrographs (cross-polarized light) and cathodoluminescence images showing: A, B) dark red luminescent fibrous to bladed calcite cement engulfed in a red luminescent intergranular calcite cement (TSU-2 quartzarenites). C, D) Partial view of red luminescent vein-filling calcite cement in a subarkose from TSU-2. 




Figure 11: Cross plot of $\delta 13 \mathrm{Cv}$-PDB versus $\delta{ }_{18} \mathrm{Ov}$-PDB of calcite cements and detrital dolomite grains and their overgrowths in the studied turbidite arenites. Authigenic dolomite in the "yellow beds" corresponds to dolomite occurring in condensed succession of the turbidite arenites of the Hecho Group (Marfil et al. in press). 

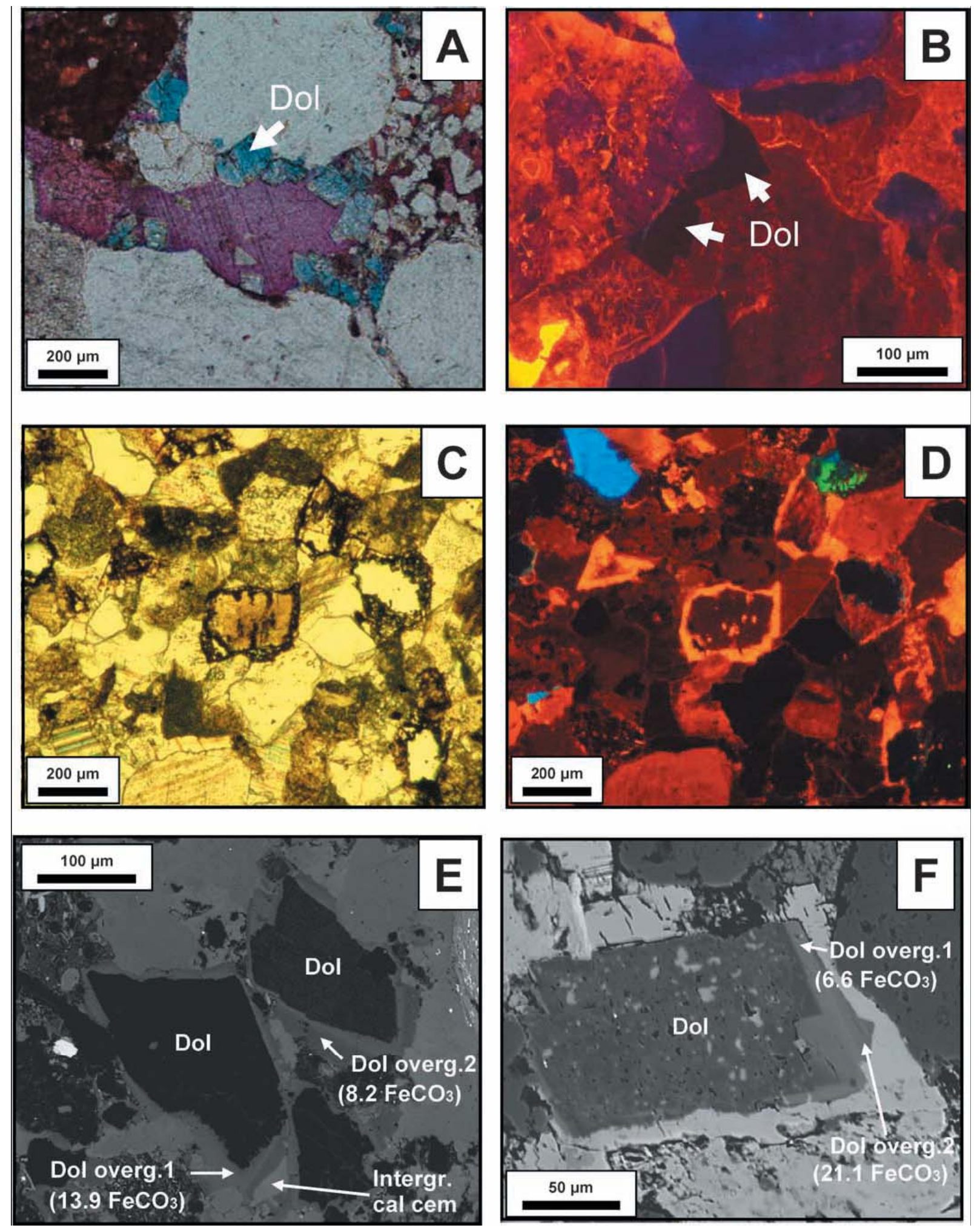

Figure 12: A) Optical photomicrograph (plane polarized) showing early dolomite (blue stained color) postdated by intergranular ferroan calcite cement (purple stained color). B) Cathodoluminescence image showing nonluminescent early dolomite cement (TSU-4). C, D) Optical photomicrograph (plane-polarized and cathodoluminescence images, respectively) of dolomite detrital grains showing the brighter luminescence of the overgrowths. E, F) BSE image of two chemical zones of dolomite overgrowths with different Fe and $\mathrm{Mn}$ contents (TSU-4). 

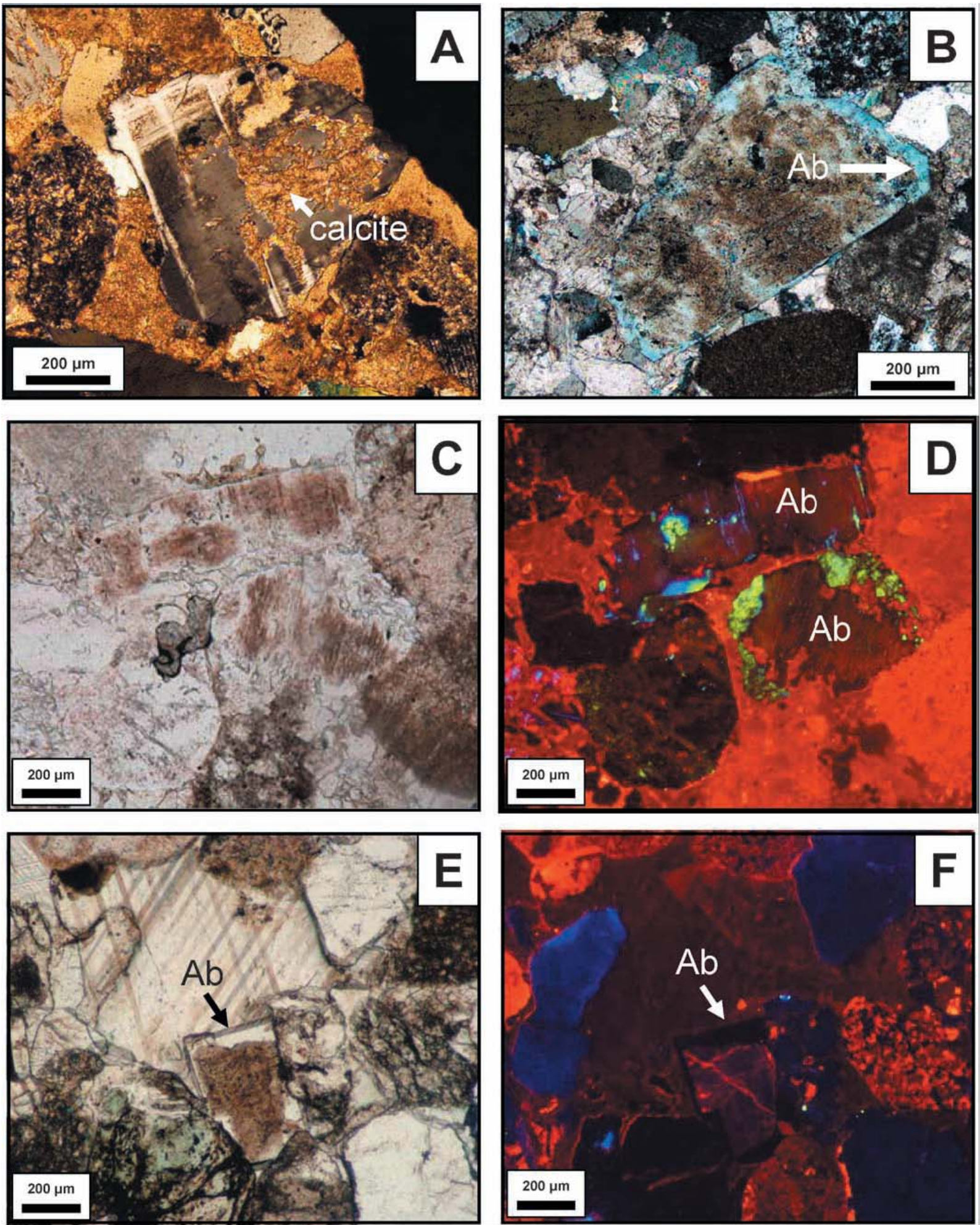

Figure 13: A) Optical photomicrograph (cross-polarized light) showing partly albitized K-feldspar (Ab). Calcite cement $(\mathrm{Ca})$ is selectively replacing the non-albitized parts of the detrital feldspar while the albitized part remained unaffected. B) Optical photomicrograph (cross-polarized light) showing albite overgrowth on Kfeldspar. C) Optical micrograph (plane-polarized light) showing turbid, vacuolated appearance, which is typical of albitized feldspars. D) CL image of Part C showing diagenetic albite (dark luminescent) replacing K-feldspar and coexisting with inherited plagioclase (green and blue luminescent). E) Optical photomicrograph (planepolarized light) showing albite overgrowths on plagioclase. F) CL image of Part E showing that the overgrowths are characterized by dark luminescence, which is typical of diagenetic albite. The diagenetic albite overgrowths on plagioclase grains are engulfed by, and hence predate, ferroan calcite cement (Ca). 


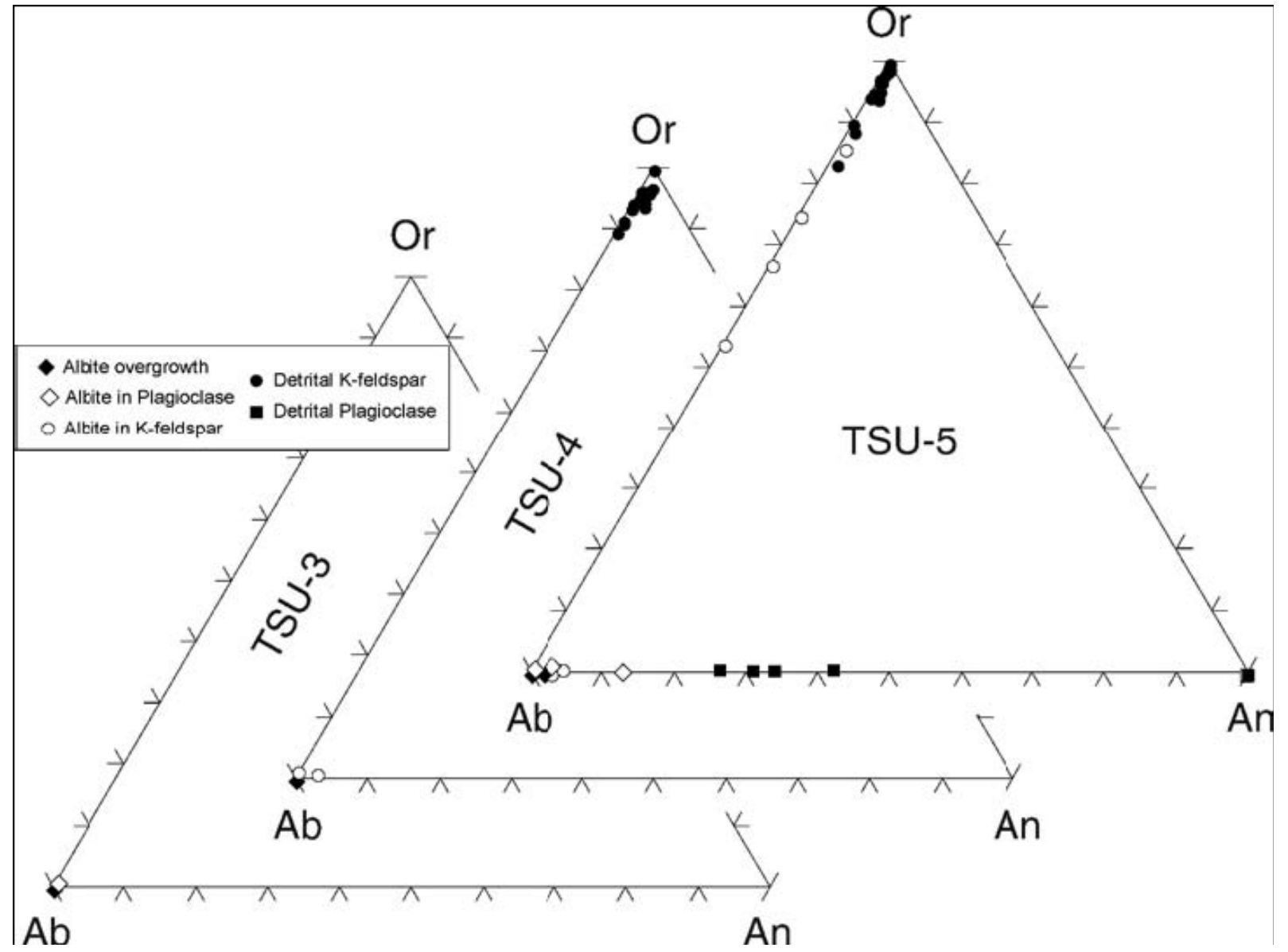

Figure 14: Ternary diagrams showing the electron-microprobe chemical composition of detrital feldspars and diagenetic albite. In contrast to detrital feldspar, albite overgrowths show pure end-member composition.

Figure 15: A) Optical photomicrograph (cross-polarized light) showing early pyrite crystals engulfed in intragranular calcite cement. B) SEM view of early diagenetic pyrite framboids within carbonate bioclasts. C) Optical photomicrograph (cross-polarized light) showing grain-to-grain contacts (TSU-4). D) Optical photomicrograph (plane-polarized light) showing concavo-convex contacts between detrital carbonate grains (CE) and foraminifera fossils (CI; TSU-4). E) Optical photomicrograph (plane-polarized light) showing sutured contacts between quartz grains (TSU-2). F) Calcite cement in fractured quartz grains. 
International J ournal of Chemical Reactor Engineering, 2009, 7, A39

doi: 10.2202/ 1542-6580.1881
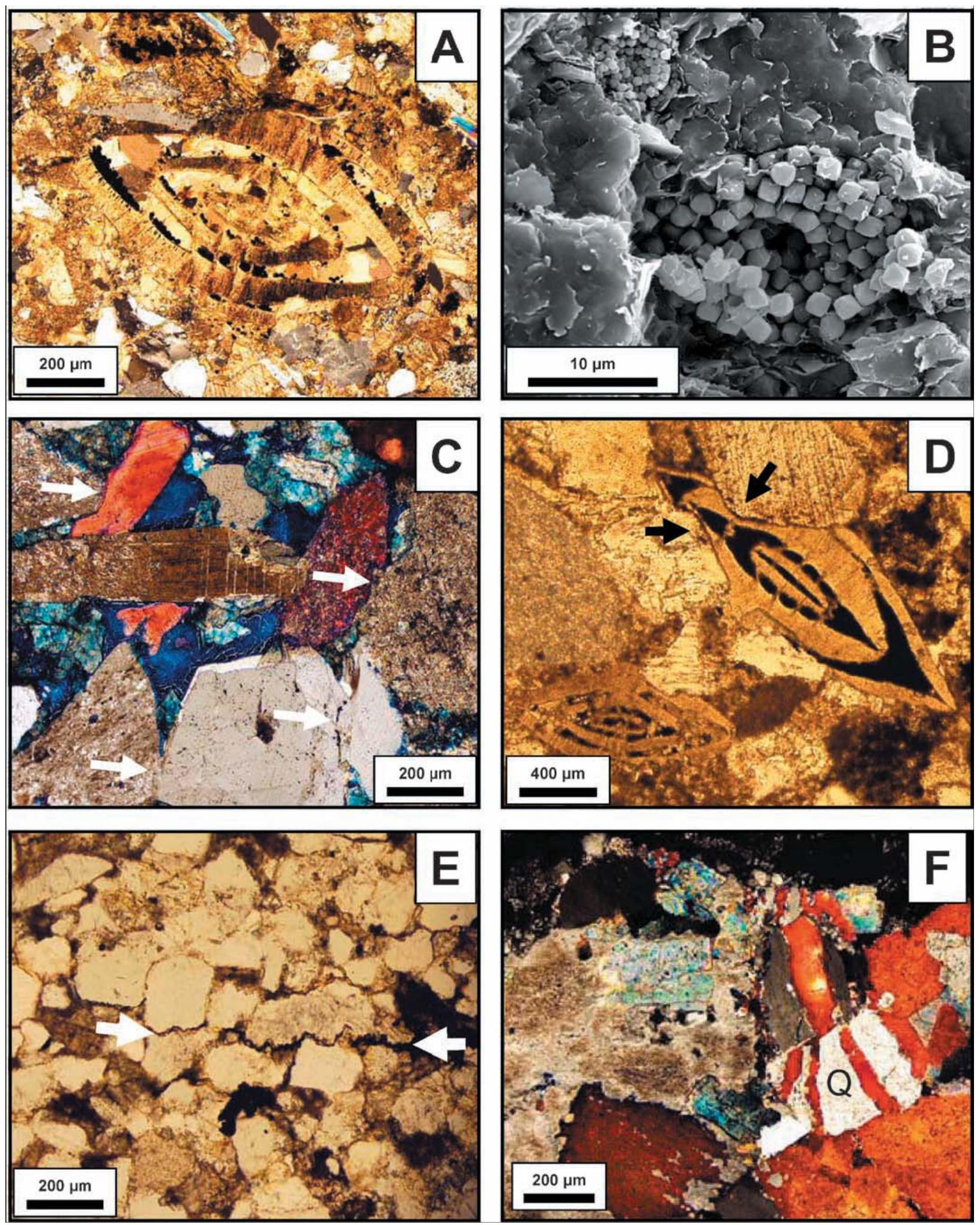

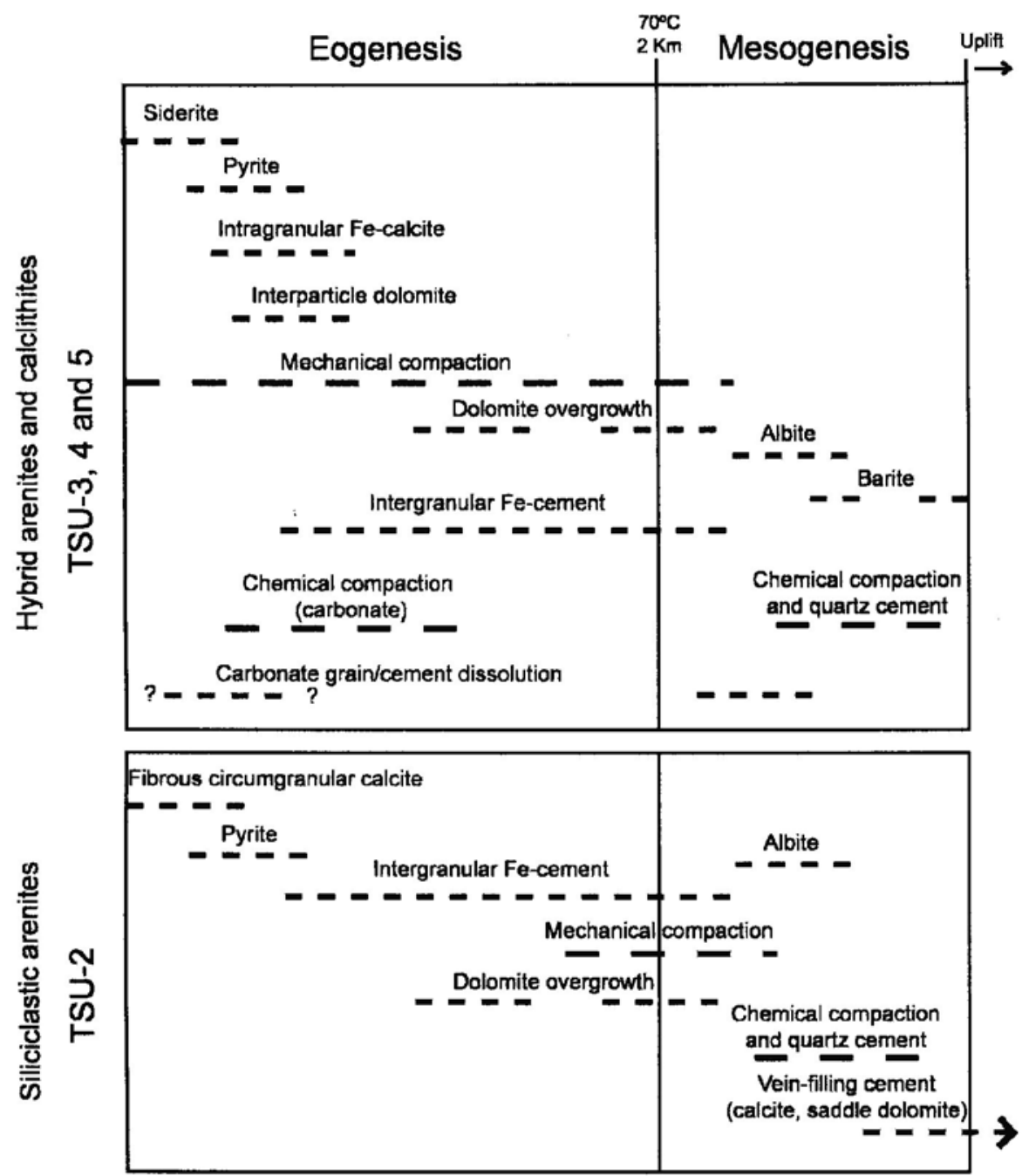

Figure 16: General paragenetic sequence of diagenetic events in the Hecho Group turbidite sandstones constructed on the basis of the textural relationships among diagenetic events.



Figure 17: Microthermometry of aqueous fluid inclusions in intergranular blocky ferroan calcite cement and in vein-filling prismatic calcites showing the higher temperatures of the vein-filling prismatic calcites and the wide range of precipitation temperatures of the intergranular calcite cement. 
International J ournal of Chemical Reactor Engineering, 2009, 7, A39 doi: 10.2202/ 1542-6580.1881

\section{Tables}

Table 1: Modal analyses of the studied arenites of the Hecho Group "tectonosedimentary units" (TSU).

\begin{tabular}{|c|c|c|c|c|c|c|c|c|c|c|c|c|c|c|c|c|c|c|c|c|c|c|c|}
\hline \multirow{2}{*}{$\begin{array}{c}\text { Tectono Sedimentary Unit } \\
\text { Turbidite Systems }\end{array}$} & & \multicolumn{3}{|c|}{ TSU-2 } & \multicolumn{16}{|c|}{ TSU-3 } & \multirow[b]{3}{*}{ TSU-3 } & \multirow[b]{3}{*}{ Calclithites } & \multirow[b]{3}{*}{$\begin{array}{c}\text { Hybrid } \\
\text { Arenites }\end{array}$} \\
\hline & & & FIGOLS & & \multicolumn{3}{|c|}{ TORLA } & $\mathrm{BRO}$ & DTO 48 & & & ROTO & & & ROTO 6 & & GERBE & & TEFAB & & & & \\
\hline Composition & & & Arenites & & Hybri & id Areni & & & Iclithites & & & Ilclithite & & Hybric & id Areni & & Calclithites & & rid Arer & nites & & & \\
\hline Number of Samples & & & 6 & & & 4 & & & 4 & & & 5 & & & 11 & & 1 & & 4 & & 29 & 10 & 19 \\
\hline & & $\min$ & $\max$. & ave. & $\min$ & $\max$. & ave. & $\min$. & $\max$ & ave. & $\min$. & $\max$. & ave. & $\min$. & $\max$. & ave. & & $\min$. & $\max$ & ave. & ave & ave. & ave. \\
\hline $\begin{array}{l}\text { Quartz monocrystalline } \\
\text { Quartz polycristalline with 2-3 }\end{array}$ & NCE & Q 30.3 & 67.0 & 50.1 & 24.3 & 42.7 & 30.3 & 32.3 & 34.3 & 33.2 & 28.7 & 34.3 & 31.5 & 12.2 & 28.3 & 20.3 & 30.1 & 10.3 & 32.9 & 23.6 & 28.2 & 31.6 & 24.7 \\
\hline $\begin{array}{l}\text { subgrains } \\
\text { Quartz polycristalline with }>3\end{array}$ & NCE & Q $\quad 2.7$ & 14.7 & 7.2 & 4.0 & 8.7 & 6.3 & 4.0 & 12.0 & 8.3 & 3.0 & 8.3 & 5.1 & 1.0 & 6.7 & 4.4 & 7.4 & 4.3 & 5.7 & 5.0 & 6.1 & 6.9 & 5.2 \\
\hline $\begin{array}{l}\text { subgrains } \\
\text { Quart in rock fragments }\end{array}$ & $\begin{array}{l}\text { NCE } \\
\text { NCE }\end{array}$ & $\begin{array}{ll}\mathrm{Q} & 0.7 \\
\mathrm{Q} & -\end{array}$ & $\stackrel{3.3}{-}$ & $\begin{array}{l}1.8 \\
-\end{array}$ & $\begin{array}{l}1.0 \\
-\end{array}$ & $\begin{array}{l}4.3 \\
5.0\end{array}$ & $\begin{array}{l}2.7 \\
1.6\end{array}$ & 3.3 & $\begin{array}{l}5.7 \\
0.7\end{array}$ & $\begin{array}{l}4.9 \\
0.3\end{array}$ & 2.0 & $\begin{array}{l}9.0 \\
1.0\end{array}$ & $\begin{array}{l}5.0 \\
0.2\end{array}$ & : & $\begin{array}{l}4.3 \\
2.5\end{array}$ & $\begin{array}{l}1.1 \\
0.9\end{array}$ & $\begin{array}{l}2.7 \\
2.3\end{array}$ & $\begin{array}{l}1.7 \\
0.3\end{array}$ & $\begin{array}{l}3.0 \\
2.0\end{array}$ & $\begin{array}{l}2.4 \\
1.1\end{array}$ & $\begin{array}{l}3.1 \\
1.1\end{array}$ & $\begin{array}{l}4.2 \\
0.9\end{array}$ & $\begin{array}{l}2.1 \\
1.2\end{array}$ \\
\hline $\begin{array}{l}\text { Carbonate replacement on } \\
\text { quartz }\end{array}$ & & - & - & . & - & - & 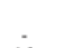 & . &  & $\therefore$ & $\cdot \cdot$ & & - & . & 3.0 & 1.3 & & $\cdot$ & - & - & 0.2 & 0.0 & 0.4 \\
\hline K-feldspar & NCE & $\mathrm{F}$ : & 2.0 & 0.6 & . & 7.3 & 1.9 & : & 2.0 & 1.3 & 0.3 & 2.3 & 1.4 & . & 2.3 & 1.0 & 1.7 & . & 2.0 & 0.8 & 1.3 & 1.5 & 1.2 \\
\hline $\begin{array}{l}\text { K-feldspar in rock fragment } \\
\text { Clay minerals replacement on }\end{array}$ & NCE & $\mathrm{F}$. & - & - & - & - & - & - & 0.3 & 0.1 & - & - & $\cdot$ & $\cdot$ & 0.3 & $\cdot$ & $\cdot$ & $\cdot$ & $\cdot$ & $\cdot$ & 0.0 & 0.0 & 0.0 \\
\hline $\begin{array}{l}\text { K-feldspar } \\
\text { Carbonate replacement on } \mathrm{K} \text { - }\end{array}$ & & - & - & - & - & 2.0 & 0.7 & - & - & - & - & - & - & - & 0.9 & 0.1 & 1.7 & - & 0.7 & 0.2 & 0.4 & 0.6 & 0.3 \\
\hline feldspar & & . & 1.0 & $\begin{array}{l}0.2 \\
0.4\end{array}$ & : & 6.7 & 2.0 & $\therefore$ & $\therefore$ & $\therefore$ & $\therefore$ & $\therefore$ & $\dot{63}$ & $\dot{0}$ & 5.0 & 0.5 & 2.3 & $\therefore$ & 1.0 & 0.4 & 0.9 & 0.8 & 1.0 \\
\hline $\begin{array}{l}\text { Plagioclase } \\
\text { Plagioclase in rock fragment }\end{array}$ & $\begin{array}{l}\text { NCE } \\
\text { NCE }\end{array}$ & $\begin{array}{l}\mathrm{F} \\
\mathrm{F}\end{array}$ & 1.3 & 0.4 & : & 1.7 & 0.6 & $\begin{array}{c}9.3 \\
-\end{array}$ & 10.7 & 9.8 & 4.0 & $\begin{array}{l}9.7 \\
1.7\end{array}$ & $\begin{array}{l}6.3 \\
0.3\end{array}$ & 2.0 & $\begin{array}{l}6.7 \\
2.3\end{array}$ & $\begin{array}{l}4.1 \\
0.3\end{array}$ & 0.7 & 0.3 & 2.3 & 1.3 & $\begin{array}{l}3.8 \\
0.1\end{array}$ & $\begin{array}{l}5.6 \\
0.1\end{array}$ & $\begin{array}{l}2.0 \\
0.1\end{array}$ \\
\hline $\begin{array}{l}\text { Clay minerals replacement on } \\
\text { plagioclase }\end{array}$ & & - & $\cdot$ & - & - & - & - & 5.7 & 7.3 & 6.7 & 3.3 & 5.7 & 4.9 & 0.7 & 5.7 & 2.6 & . & . & 0.3 & 0.2 & 2.4 & 3.8 & 0.9 \\
\hline $\begin{array}{l}\text { Carbonate replacement on } \\
\text { plagioclase }\end{array}$ & & - & 1.7 & 0.8 & - & 1.3 & 0.5 & - & 1.3 & 0.3 & - & 3.3 & 1.6 & 0.7 & 7.0 & 2 & - & - & 3.0 & 1.1 & 1.3 & 0.6 & 1.9 \\
\hline Metamorphic rock fragment & NCE 1 & $\mathrm{~L} \quad$. & 0.7 & 0.2 & . & : & - & . & 0.7 & 0.3 & 0.3 & 2.7 & 1.6 & $\because$ & 2.0 & 0.6 & . & . & 0.3 & 0.1 & 4 & 0.6 & 0.2 \\
\hline Plutonic r & NCE $\mathrm{I}$ & $\mathrm{L}$. & $\because$ & - & . & 3.7 & 1.5 & . & 1.0 & 0.3 & - & 1.0 & 0.3 & . & 0.3 & $\cdot$ & 0.3 & . & 2.0 & 0.6 & & a & 0.7 \\
\hline Volcanic rock $\mathrm{f}$ & NCE 1 & L . & - & . & - & : & - & - & - & - & . & 0.3 & 0.1 & . & . & - & . & . & . & - & 0 & 0.0 & 0.0 \\
\hline Sandstone rock fragment & NCE & $\mathrm{L} \quad$ - & 0.3 & 0.1 & - & 3.0 & 1.1 & 1.0 & 2.7 & 1.8 & - & 2.7 & 1.3 & - & 5.9 & 2.6 & 0.3 & - & 2.3 & 1.0 & 3 & 1.1 & 1.6 \\
\hline Shale rock fragment & NCE 1 & $\mathrm{~L} \quad$ - & - & - & . & . & $\because$ & - & 0.3 & 0.1 & . & $\because$ & $\because$ & - & 0.3 & 1 & - & . & $\because$ & . & 0 & 0.0 & 0.0 \\
\hline Chert & NCE $\mathrm{I}$ & $\mathrm{L} \quad$. & 1.3 & 0.6 & 0.7 & 4.3 & 2.2 & 1.3 & 4.3 & 3.1 & 1.0 & 7.0 & 2.9 & . & 2.7 & 8 & 5.0 & 1.7 & 4.3 & 3.3 & 9 & 3.7 & 2.1 \\
\hline Mica & & - & 2.7 & 0.6 & $\cdot$ & 0.7 & 0.3 & $\because$ & 1.3 & 0.6 & 0.7 & 2.7 & 1.4 & . & 4.7 & 1.5 & 1.0 & $\because$ & - & . & 0.8 & 1.0 & 0.6 \\
\hline Mica in metamorphic rock & & & & & & & & & & & & & & & & & & & & & & & \\
\hline fragments & & - & - & - & - & - & - & - & - & - & - & - & - & - & 0.3 & - & - & - & - & - & 0.0 & 0.0 & 0.0 \\
\hline $\begin{array}{l}\text { Stable heavy minera } \\
\text { rutile, tourmaline, }\end{array}$ & & $\theta$ & & 07 & . & 03 & & . & . & & . & 07 & 0.3 & . & 07 & 02 & . & . & & & 1 & 01 & 01 \\
\hline Organic matter & & . & 0.7 & 0.1 & . & . & - & : & : & : & . & 2.0 & 1.1 & . & 2.7 & 0.7 & . & : & 0.7 & 0.2 & 3 & 0.4 & 0.3 \\
\hline Phosphates & $\mathrm{NCI}$ & . & - & - & . & . & . & . & . & . & . & - & $\cdot$ & . & . & - & . & . & - & - & 0.0 & 0.0 & 0.0 \\
\hline Pelitic rip-up clast & $\mathrm{NCI}$ & - & - & - & - & - & - & - & - & - & - & - & - & - & - & - & - & - & - & - & 0.0 & 0.0 & 0.0 \\
\hline $\begin{array}{l}\text { Monocrystalline sparitic } \\
\text { limestone }\end{array}$ & & & & & & & & & & & & & & & & & & & & & & & \\
\hline $\begin{array}{l}\text { limeston } \\
\text { Sparitic lii }\end{array}$ & CE & - & 5.3 & 1.6 & 4.0 & 8.1 & 6.3 & 0.3 & 12.0 & 5.2 & 3.3 & 12.0 & 6.2 & 1.3 & 20.7 & 8.8 & 2.0 & 4.3 & 10.6 & 7.9 & 6.1 & 4.5 & 7.7 \\
\hline estone & $\mathrm{CE}$ & - & 1.3 & 0.3 & - & 5.4 & 2.2 & 1.0 & 3.3 & 1.8 & 1.7 & 5.3 & 3.1 & 2.0 & 6.7 & 4.1 & 2.3 & 2.0 & 7.0 & 4.4 & 3.0 & 2. & 3.6 \\
\hline mestone & c & 3.0 & 10.7 & 6.6 & 6.0 & 14.8 & 10.2 & 5.3 & 12.0 & 7.9 & 3.0 & 7.7 & 5.1 & 3.4 & 16.7 & 9.1 & 11.4 & 17.1 & 21.3 & 19.4 & 10.5 & 8.1 & 12.9 \\
\hline & c & . & 13.0 & 2.4 & $\because$ & 2.7 & 1.3 & $\because$ & 0.7 & 0.3 & 3.0 & $\cdots$ & 5.1 & $\because$ & 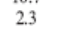 & . & 2.0 & $\cdot$. & 21.0 & 19.4 & 10.2 & 0.1 & 0.7 \\
\hline Dolomicrite & $\mathrm{CE}$ & - & - & - & - & - & - & - & - & - & - & 1.0 & 0.3 & . & 2.0 & 0.3 & & - & . & - & 0.1 & 0.1 & 0.1 \\
\hline Grainstone & $\mathrm{CE}$ & - & 0.7 & 0.2 & $\therefore$ & 2.0 & 0.5 & 2.7 & 5.0 & 3.3 & - & 1.7 & 0.6 & . & 4.3 & 1.2 & 0.3 & 1.0 & 1.7 & 1.3 & 1.2 & 1.4 & 1.0 \\
\hline ils (micro & $\mathrm{CE}$ & 0.7 & 3.7 & 1.6 & 1.3 & 3.0 & 2.3 & 0.7 & 4.7 & 2.5 & . & 1.3 & 0.3 & . & 3.3 & 0.4 & 0.7 & 2.7 & 5.3 & 3.9 & i. & 1.1 & 2.2 \\
\hline Detrital d & $\mathrm{CE}$ & 2.3 & 2.3 & 0.4 & 6.7 & 6.7 & 1.7 & $\because$ & . & $\because$ & . & $\because$ & . & . & 6.7 & 0.6 & 4.7 & 0.7 & 3.3 & 1.3 & 1.4 & 1.6 & 1.2 \\
\hline Bioclast & $\mathrm{CI}$ & . & 7.6 & 2.2 & 2.3 & 20.7 & 8.3 & . & 1.3 & 0.8 & . & 2.7 & 1.1 & . & 15.9 & 4.1 & $\because$ & 1.0 & 13.7 & 4.7 & 3. & 0.7 & 5.7 \\
\hline Intraclast & $\mathrm{CI}$ & - & . & - & - & - & - & - & . & - & . & - & - & - & . & - & - & - & - & . & 0.0 & 0.0 & 0.0 \\
\hline Tectono Sedimentary Unit & & & TSU-2 & & & & & & & & & & ISU-3 & & & & & & & & & & \\
\hline Turbidite Systems & & & FIGOLS & & & TORLA & & $\mathrm{BRC}$ & OTO 48 & & & ROTO & & & ROTO 6 & & GERBE & & TEFAB & LO & & & \\
\hline Composition & & & Arenites & & Hybr & rid Aren & & & Iclithite & & & alclithite & & Hybri & id Aren & nites & Calclithites & & rid Arer & nites & TSU-3 & Calclithites & $\begin{array}{l}\text { Hybrid } \\
\text { Arenites }\end{array}$ \\
\hline Number of Samples & & & 6 & & & 4 & & & 4 & & & 5 & & & 11 & & 1 & & 4 & & 29 & 10 & 19 \\
\hline & & $\min$ & n. $\quad \max$. & ave. & $\min$ & $\max$. & ave. & $\min$. & $\max$ & ave. & $\min$. & $\max$ & ave. & $\min$. & $\max$ & ave. & & $\min$. & $\max$ & ave. & ave. & ave. & ave. \\
\hline Peloid & $\mathrm{CI}$ & - & - & - & . & - & . & . & - & . & - & - & - & . &  & . & - & . & - & . & 0.0 & 0.0 & 0.0 \\
\hline Calcite & & 3.7 & $7 \quad 47.3$ & 15.3 & 6.0 & 21.5 & 10.8 & . & 10.0 & 4.9 & - & 18.0 & 9.9 & 2.0 & 26.3 & 18.2 & 9.0 & 3.3 & 21.3 & 11.9 & & & \\
\hline Replaci & & : & - & - & . & $\because$ & . & . & . & . & - & - & : & . & . & . & 8.0 & . & - & : & & 0 & 0 \\
\hline $\mathrm{Re}$ & & - & 1.7 & 0.3 & - & $\therefore$ & $\therefore$ & - & $\therefore$ & $\therefore$ & - & $\therefore$ & $\therefore$ & - & $\therefore$ & $\therefore$ & 1.7 & - & - & - & & 6 & 0.0 \\
\hline Dolomite cem & & . & 22.6 & 4.8 & . & 3.0 & 0.8 & . & 0.3 & 0.1 & . & 2.7 & 1.5 & . & 2.0 & 0.7 & . & . & - & . & 0.5 & 0.5 & 0.5 \\
\hline Replacive dol & & . & - & - & - & 2.0 & 0.5 & . & - & . & - & - & $=$ & - & - & - & . & . & . & . & 0. & 0.0 & 0.2 \\
\hline Albitizatic & & - & - & - & . & 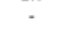 & - & . & - & . & - & - & - & . & . & . & - & - & - & . & 0.0 & 0.0 & 0.0 \\
\hline Other & & & & & & & & & & & & & & & & & & & & & & & \\
\hline Fe-ox & & - & 1.3 & 0.7 & 0.3 & 2.3 & 1.0 & - & - & - & - & $\therefore$ & $\therefore$ & - & 2.7 & . & 5.0 & $\therefore$ & 1.3 & 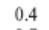 & & 1.7 & 0.6 \\
\hline Pyrite & & - & 1.3 & 0.3 & - & 1.0 & 0.3 & . & . & . & - & 0.3 & 0.1 & . & 0.9 & 0.3 & - & 0.3 & 1.0 & 0.7 & 0.2 & 6 & 0.4 \\
\hline Siliciclastic & & - & . & - & . & - & . & . & . & . & - & - & - & . & - & . & . & - & - & . & 0.0 & 0. & 0. \\
\hline Carbonate n & & . & . & - & . & . & . & . & 0.7 & 0.3 & - & 1.0 & 0.3 & . & 1.3 & & . & . & - & - & & & 0.1 \\
\hline $\mathrm{Ca}$ & & . & . & . & . & . & . & . & 3.7 & 1.5 & - & 2.7 & 1.2 & 0.6 & 9.0 & 3.4 & . & - & - & . & 1.0 & 0.9 & 1.1 \\
\hline Carbonate undetermined grains & & - & - & - & - & 6.0 & 2.3 & - & 0.7 & 0.2 & - & - & - & - & 0.7 & 0.1 & 5.4 & 0.7 & 4.0 & 2.9 & 1.8 & 1.8 & 1.8 \\
\hline $\begin{array}{l}\text { Porosity } \\
\text { Ple }\end{array}$ & & . & . & . & . &  & $\because$ & . &. & 0. & . & . & . & . & 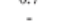 & :.1. & 1.4 &. & 7.0 & $\because$ & 0.0 & 0.0 & 0.0 \\
\hline
\end{tabular}


International J ournal of Chemical Reactor Engineering, 2009, 7, A39 doi: 10.2202/1542-6580.1881

Table 2: Summary of elemental composition of diagenetic carbonate cements obtained by electron microprobe analysis showing the chemical differences between the diagenetic carbonates in the Hecho Group "tectonosedimentary units" (TSU).

\begin{tabular}{|c|c|c|c|c|c|c|}
\hline & $n$ & $\mathrm{Ca}(\mathrm{mole} \%)$ & $\mathrm{Mg}($ mole $\%)$ & $\mathrm{Fe}(\mathrm{mole} \%)$ & Mn (mole \%) & $\mathrm{Sr}(\operatorname{mole} \%)$ \\
\hline Fibrous calcite cement ( TSU-2) & 24 & 97.5 & 1.1 & 0.8 & 0.1 & 0.5 \\
\hline \multicolumn{7}{|l|}{ Interparticle ferroan cement } \\
\hline TSU-5 & 14 & 97.3 & 0.5 & 2.0 & 0.1 & 0.1 \\
\hline TSU-4 & 32 & 97.2 & 1.2 & 1.4 & 0.1 & 0.1 \\
\hline TSU-3 & 27 & 96.1 & 1.5 & 2.0 & 0.1 & 0.3 \\
\hline \multicolumn{7}{|l|}{ Intraparticle ferroan cement } \\
\hline TSU-5 & 4 & 98.2 & 0.2 & 1.4 & 0.1 & 0.1 \\
\hline TSU-4 & 19 & 95.3 & 2.2 & 2.0 & 0.1 & 0.4 \\
\hline TSU-3 & 19 & 96.6 & 1.4 & 1.9 & 0.1 & 0 \\
\hline Dolomite overgrowth 1 (TSU-4 and 5) & 28 & 56.5 & 33.4 & 9.8 & 0.1 & 0.1 \\
\hline Dolomite overgrowth 2 (TSU-4 and 5) & 5 & 57.3 & 28.3 & 13.4 & 0.4 & 0 \\
\hline Vein-filling calcite cement & 69 & 97.3 & 1.0 & 1.4 & 0.1 & 0.2 \\
\hline
\end{tabular}

$\mathrm{n}$ : number of analyses.

Table 3: Summary of elemental composition of diagenetic carbonate cements obtained by electron microprobe analysis showing the chemical differences between the diagenetic carbonates in the Hecho Group "tectonosedimentary units" (TSU).

\begin{tabular}{|c|c|c|c|c|c|c|}
\hline & $n$ & $(\mathrm{ppm})$ & $\mathrm{Fe}$ & $\mathrm{Mn}$ & $\mathrm{Ba}$ & $\mathrm{Sr}$ \\
\hline Fibrous calcite cement (TSU-2) & 24 & $\begin{array}{c}\text { Min. } \\
\text { Max. } \\
\text { Av. }\end{array}$ & $\begin{array}{l}2340 \\
6179 \\
4540\end{array}$ & $\begin{array}{l}<\text { d.l. } \\
720 \\
279\end{array}$ & $\begin{array}{l}<\text { d.l. } \\
484 \\
109\end{array}$ & $\begin{array}{l}1640 \\
5978 \\
4399\end{array}$ \\
\hline \multicolumn{7}{|l|}{ Interparticle ferroan calcite cement } \\
\hline TSU-5 & 14 & $\begin{array}{c}\text { Min. } \\
\text { Max. } \\
\text { Av. }\end{array}$ & $\begin{array}{r}7594 \\
15103 \\
10929\end{array}$ & $\begin{array}{c}<\text { d.l. } \\
1154 \\
654\end{array}$ & $\begin{array}{l}<\text { d.1. } \\
869 \\
212\end{array}$ & $\begin{array}{c}<\text { d.l. } \\
2241 \\
444\end{array}$ \\
\hline TSU-4 & 32 & $\begin{array}{l}\text { Min. } \\
\text { Max. } \\
\text { Av. }\end{array}$ & $\begin{array}{r}630 \\
13548 \\
7808\end{array}$ & $\begin{array}{c}<\text { d.l. } \\
1231 \\
635\end{array}$ & $\begin{array}{c}<\text { d.l. } \\
1424 \\
267\end{array}$ & $\begin{array}{c}<\text { d.l. } \\
2841 \\
252\end{array}$ \\
\hline TSU-3 & 27 & $\begin{array}{l}\text { Min. } \\
\text { Max. } \\
\text { Av. }\end{array}$ & $\begin{array}{r}1290 \\
15219 \\
11313\end{array}$ & $\begin{array}{c}<\text { d.l. } \\
1115 \\
530\end{array}$ & $\begin{array}{c}<\text { d.l. } \\
2553 \\
375\end{array}$ & $\begin{array}{l}<\text { d.l. } \\
6875 \\
2424\end{array}$ \\
\hline \multicolumn{7}{|l|}{ Intraparticle ferroan calcite cement } \\
\hline TSU-5 & 4 & $\begin{array}{c}\text { Min. } \\
\text { Max. } \\
\text { Av. }\end{array}$ & $\begin{array}{r}4500 \\
12996 \\
7662\end{array}$ & $\begin{array}{l}<\text { d.l. } \\
813 \\
461\end{array}$ & $\begin{array}{c}<\text { d.l. } \\
1585 \\
734\end{array}$ & $\begin{array}{l}<\text { d.l. } \\
3069 \\
1131\end{array}$ \\
\hline TSU-4 & 19 & $\begin{array}{l}\text { Min. } \\
\text { Max. } \\
\text { Av. }\end{array}$ & $\begin{array}{r}3070 \\
15981 \\
11844\end{array}$ & $\begin{array}{l}<\text { d.l. } \\
829 \\
376\end{array}$ & $\begin{array}{c}<\text { d.1. } \\
1317 \\
315\end{array}$ & $\begin{array}{c}<\text { d.l. } \\
12143 \\
3375\end{array}$ \\
\hline TSU-3 & 19 & $\begin{array}{c}\text { Min. } \\
\text { Max. } \\
\text { Av. }\end{array}$ & $\begin{array}{r}8434 \\
13222 \\
10729\end{array}$ & $\begin{array}{c}<\text { d.l. } \\
1154 \\
581\end{array}$ & $\begin{array}{c}<\text { d.l. } \\
1505 \\
281\end{array}$ & $\begin{array}{l}<\text { d. } 1 . \\
<\text { d. } 1 . \\
<\text { d. } .1 .\end{array}$ \\
\hline Dolomite overgrowth 1 (TSU-4 and 5) & 28 & $\begin{array}{c}\text { Min. } \\
\text { Max. } \\
\text { Av. }\end{array}$ & $\begin{array}{l}12071 \\
84009 \\
61156\end{array}$ & $\begin{array}{c}<\text { d.l. } \\
1928 \\
633\end{array}$ & $\begin{array}{c}<\text { d.1. } \\
1352 \\
362\end{array}$ & $\begin{array}{c}<\text { d.l. } \\
3830 \\
502\end{array}$ \\
\hline Dolomite overgrowth 2 (TSU-4 and 5) & 5 & $\begin{array}{c}\text { Min. } \\
\text { Max. } \\
\text { Av. }\end{array}$ & $\begin{array}{r}46450 \\
112418 \\
72264\end{array}$ & $\begin{array}{l}1789 \\
2548 \\
1983\end{array}$ & $\begin{array}{l}<\text { d.l. } \\
448 \\
113\end{array}$ & $\begin{array}{l}<\text { d. } 1 . \\
<\text { d. } . \\
<\text { d. } .\end{array}$ \\
\hline Vein-filling calcite cement & 69 & $\begin{array}{l}\text { Min. } \\
\text { Max. } \\
\text { Av. }\end{array}$ & $\begin{array}{c}<\text { d.l. } \\
17551 \\
7855\end{array}$ & $\begin{array}{c}<\text { d.l. } \\
1394 \\
549\end{array}$ & $\begin{array}{c}<\text { d.l. } \\
2920 \\
328\end{array}$ & $\begin{array}{l}<\text { d.l. } \\
9572 \\
1717\end{array}$ \\
\hline
\end{tabular}

n: number of analyses.

$<$ d.l.: below detection limit. 
International J ournal of Chemical Reactor Engineering, 2009, 7, A39

doi: 10.2202/1542-6580.1881

Table 4: Summary of stable carbon and oxygen isotope analyses of calcite cements, detrital dolomite, and their overgrowth of the Hecho Group "tectonosedimentary units” (TSU)

\begin{tabular}{|c|c|c|c|c|c|c|c|c|c|}
\hline Sample & Site & TSU & System & Type of Cement & $\begin{array}{c}\text { Calcite } \\
{ }^{18} \mathrm{O}_{\mathrm{PDB}} \\
\end{array}$ & $\begin{array}{c}\text { Calcite }^{13} \\
\mathrm{C}_{\mathrm{PDB}}\end{array}$ & Type of Cement & $\begin{array}{c}\text { Dolomite } \\
{ }^{18} \mathrm{O}_{\mathrm{PDB}} \\
\end{array}$ & $\begin{array}{l}\text { Dolomite } \\
{ }^{13} \mathrm{C}_{\mathrm{PDB}}\end{array}$ \\
\hline$\overline{\mathrm{GH}} 100$ & LaTorrecilla & TSU5 & Guaso & Intergranular calcite & -5.82 & -0.12 & Dolomite in YB & -5.48 & 0.84 \\
\hline GH101B & LaTorrecilla & TSU5 & Guaso & Intergranular calcite & -6.11 & 0.24 & Dolomite in YB & -6.20 & 1.61 \\
\hline GH101G2 & LaTorrecilla & TSU5 & Guaso & Intergranular calcite & -5.94 & 0.27 & Dolomite in YB & -6.73 & 2.17 \\
\hline GH101G3 & LaTorrecilla & TSU5 & Guaso & Intergranular calcite & -5.57 & 0.35 & Dolomite in YB & -6.72 & 1.67 \\
\hline CGG01C & LaTorrecilla & TSU5 & Guaso & Intergranular calcite & -6.64 & -0.59 & Dolomite in YB & -7.23 & 1.96 \\
\hline CGB2-01 & SanVicente & TSU4 & Banaston3 & Intergranular calcite & -7.07 & -0.34 & Dolomite in YB & -9.98 & 0.99 \\
\hline CGB2-02y1 & SanVicente & TSU4 & Banaston3 & Intergranular calcite & -6.73 & -2.50 & Dolomite in YB & -10.13 & 0.42 \\
\hline CGB2-02y 2 & SanVicente & TSU4 & Banaston3 & Intergranular calcite & -6.87 & -2.70 & Dolomite in YB & -10.38 & 0.37 \\
\hline CGB2 $2-02 \mathrm{gr}$ & SanVicente & $\begin{array}{l}\text { TSU4 } \\
\text { TSU }\end{array}$ & Banaston3 & Intergranular calcite & $\begin{array}{l}-6.01 \\
-6.61\end{array}$ & -1.64 & Dolomite in $\mathrm{YB}$ & -8.23 & $\begin{array}{l}-0.28 \\
-0.28\end{array}$ \\
\hline $\mathrm{CGB} 2-03 \mathrm{~B}$ & SanVicente & TSU4 & Banaston3 & Intergranular calcite & -6.77 & -1.58 & Dolomite in YB & -8.72 & -0.02 \\
\hline GH01A & Labuerda & TSU4 & Banaston2 & Intergranular calcite & -6.50 & -0.12 & Dolomite in YB & -7.87 & -0.29 \\
\hline $\mathrm{GH} 01 \mathrm{~B} 1$ & Labuerda & TSU4 & Banaston2 & Intergranular calcite & -7.05 & -0.03 & Dolomite in YB & -10.17 & 0.84 \\
\hline GH01 B3 & Labuerda & TSU4 & Banaston2 & Intergranular calcite & -6.92 & 0.22 & Dolomite in YB & -9.97 & 0.74 \\
\hline$O G B 1-01$ & Usana & TSU4 & Banaston2 & Intergranular calcite & -6.66 & -0.37 & Dolomite in YB & -8.32 & 0.66 \\
\hline CGB1-02 & Usana & TSU4 & Banaston2 & Intergranular calcite & -6.48 & -1.36 & Dolomite in YB & -8.56 & -0.05 \\
\hline $\mathrm{GH} 18 \mathrm{~A} 3$ & Usana & TSU4 & Banaston & Intergranular calcite & -7.66 & -1.70 & Detrital dolomite \& overgrowth & -7.14 & -1.17 \\
\hline GH31A6 & Bergua & TSU4 & Banaston & Intergranular calcite & -6.81 & -0.65 & Detrital dolomite \& overgrowth & -5.75 & 0.72 \\
\hline GH163A & CarBolt & TSU4 & Banaston & Intergranular calcite & -6.70 & -0.07 & Detrital dolomite \& overgrowth & -6.11 & 0.36 \\
\hline GH18 & Usana & TSU4 & Banaston & Vein-filling calcite (prismatic) & -7.85 & -1.82 & & & \\
\hline $\mathrm{GH} 22 \mathrm{~B}$ & Arro & TSU3 & Broto6 & Intergranular calcite & -7.98 & -1.37 & Dolomite in YB & -8.37 & -0.01 \\
\hline $\mathrm{GH} 23 \mathrm{~B}$ & Arro & TSU3 & Broto6 & Intergranular calcite & -7.32 & -1.73 & Dolomite in YB & -10.14 & 0.25 \\
\hline $\mathrm{GH} 26 \mathrm{Al}$ & Arro & TSU3 & Broto6 & Intergranular calcite & -8.07 & -0.69 & Dolomite in YB & -9.68 & 0.63 \\
\hline $\mathrm{GH} 26 \mathrm{~A} 2$ & Arro & TSU3 & Broto6 & Intergranular calcite & -7.91 & -0.67 & Dolomite in YB & -9.22 & 0.71 \\
\hline $\mathrm{GH} 231 \mathrm{~A} 4$ & Estrech & TSU3 & Gerbe & Intergranular calcite & -7.94 & -1.77 & & & \\
\hline $\mathrm{GH} 25 \mathrm{~B} 4$ & Arro & TSU3 & Broto & Intergranular calcite & -8.16 & -0.59 & Detrital dolomite \& overgrowth & -7.38 & 0.04 \\
\hline GH294A1 & Arro & TSU3 & Broto & Intergranular calcite & -8.37 & -0.95 & Detrital dolomite \& overgrowth & -8.52 & -0.81 \\
\hline GH61A7 7 & Fanlo & TSU3 & Broto & Intergranular calcite & -8.50 & -1.27 & Detrital dolomite \& overgrowth & -6.83 & 0.18 \\
\hline GH264A & Cotefablo & TSU3 & Cotefablo & Intergranular calcite & -5.87 & -0.70 & Detrital dolomite \& overgrowth & -6.42 & 0.33 \\
\hline $\mathrm{GH} 228$ & Fuebas & TSU3 & Torla & Intergranular calcite & -10.01 & -1.53 & Detrital dolomite \& overgrowth & -6.28 & 0.31 \\
\hline $\mathrm{GH} 25 \mathrm{~B}$ & Arro & TSU3 & Broto & Vein-filling calcite (blocky) & -8.71 & -0.75 & & & \\
\hline $\mathrm{GH}_{2} 294$ & Arro & TSU3 & Broto & Vein-filling calcite (blocky) & -8.14 & -1.08 & & & \\
\hline GH61 & Fanlo & TSU3 & Broto & Vein-filling calcite (prismatic) & -10.42 & -1.38 & & & \\
\hline $\mathrm{GH} 206$ & Fuebas & TSU2 & Figols & Intergranular calcite & -9.67 & -2.01 & Detrital dolomite \& overgrowth & -6.42 & 0.69 \\
\hline GH212 & Fuebas & TSU2 & Figols & Fibrous calcite & -9.73 & 0.72 & & & \\
\hline $\mathrm{GH} 226 \mathrm{~A}$ & Fuebas & TSU2 & Figols & Fibrous calcite & -9.68 & 0.38 & & & \\
\hline GH215 & Fuebas & TSU2 & Figols & Vein-filling calcite (prismatic) & -9.55 & -1.36 & & & \\
\hline
\end{tabular}

Table 5: Summary of electron microprobe chemical analyses on albite and detrital feldspars showing a pure end member composition of the albite overgrowth.



$+:$ presence. 